Published in Proceedings of the Geologist's Association, 2009, Volume 120, pages 34-48.

\title{
Patterns of preglacial sedimentation and glaciotectonic deformation within early Middle Pleistocene sediments at Sidestrand, north Norfolk, UK Jonathan R. Lee ${ }^{1,2}$
}

\begin{abstract}
Middle Pleistocene preglacial and glacial sediments are described from Sidestrand in north Norfolk, UK. The sequence consists of estuarine and fluvial deposits of the Wroxham Crag and Cromer Forest-bed formations that were deposited by, and adjacent to, a major river system that drained northern and central England during the 'Cromerian Complex'. These preglacial sediments were subsequently overridden and partially tectonised during a glaciation that deposited till of the Happisburgh Formation associated with the first lowland glaciation of eastern England. Detailed examination of the stratigraphy and structural evolution of the sequence reveals that glaciotectonic rafts of Sidestrand Unio Bed material, a regionally important biostratigraphic marker horizon, have been remobilised and partially mixed with other lithologies whilst being transported and emplaced further up-sequence by glaciotetconic processes. Caution should therefore be exercised when examining this deposit for biostratigraphic and palaeoenvironmental purposes to ensure that sampling is from in situ material.
\end{abstract}

Key words: Pleistocene, East Anglia, preglacial, glaciotectonic.

${ }^{1}$ British Geological Survey, Keyworth, Nottingham, NG12 5GG. Email: jrlee@bgs.ac.uk ${ }^{2}$ Department of Geography, Royal Holloway, University of London, Egham, Surrey, TW20 OEX.

\section{INTRODUCTION}

Eastern England is a critical area in contributing to an understanding of landscape evolution during the late Early and early Middle Pleistocene (Mitchell et al., 1973; Bowen et al., 1986; Bowen, 1999). Palaeoenvironmental change in mid-latitude areas such as the Southern North Sea region, were largely forced by global-scale climatic fluctuations that acted to drive changes in sea-level, terrestrial (fluvial and soil) processes and ice sheet 
Published in Proceedings of the Geologist's Association, 2009, Volume 120, pages 34-48.

growth / decay (Funnell, 1995; Rose et al., 2001; Lee et al., 2006). The Pleistocene geological record of the Southern North Sea region details the effects and geomorphic consequences of these cyclic environmental changes.

In northern East Anglia, the Early and Middle Pleistocene geological record has proved somewhat of an enigma, because traditionally much of the stratigraphy has been constrained by pollen assemblage biostratigraphy and this approach is beset by numerous practical and resolution issues (Tzedakis et al., 2001). Recent geological and stratigraphic investigations of the preglacial deposits in north Norfolk have involved the examination of other biostratigraphic proxies (Preece \& Parfitt, 2000; Preece, 2001), and the classification of clastic deposits based upon their genetic and lithological properties (Rose et al., 1996; Briant et al., 1999; Lee, 2003; Pawley et al., 2004). Despite these advances, workers have been hampered by a lack of available study sites due to the absence of working quarries and the progressive deterioration of many of the coastal cliff sections.

In recent years, new sections through part of the preglacial sequence have become periodically exposed at Sidestrand on the north Norfolk coast as cliff falls have been progressively removed by coastal erosion. This site is important in enhancing our understanding of the subtle interplay between coastal and fluvial processes which dominate this part of the geological record within East Anglia (Rose et al., 2001, 2002). Sidestrand is also an important locality within the debate surrounding the earliest lowland glaciation of eastern England due to apparent occurrence beneath Happisburgh Formation glacial sediments of stratigraphically significant organic deposits (Sidestrand Unio Bed) of the Cromer Forest-bed Formation (Preece, 2001; Preece et al., 2008). The purpose of this study is two-fold: (1) to examine the palaeoenvironmental evolution of the Sidestrand area relative to its wider stratigraphic and palaeogeographic context; (2) to determine the precise stratigraphic position of the Sidestrand Unio Bed and its relationship to the basal glaciogenic deposits.

\section{SITE LOCATION AND GEOLOGICAL CONTEXT}

Sidestrand (National Grid Reference: TG 263395) is situated on the northeast Norfolk coast (Figure 1a). The geology of the Sidestrand area was first examined by Reid (1882), who 
Published in Proceedings of the Geologist's Association, 2009, Volume 120, pages 34-48.

identified a tripartite preglacial succession comprising a "Forest-bed", overlain by the "Upper Freshwater Bed" (including the "Sidestrand Unio Bed"), and an upper "Leda myalis Bed". The preglacial sequence is capped by till (Reid, 1882) which corresponds to the First Cromer Till (Banham, 1968), Happisburgh Diamicton (Hart, 1992; Lunkka, 1994) or Happisburgh Till Member (Lee et al., 2004a). The preglacial sequences at adjacent localities were examined by West (1980), but many of the coastal sections in the Sidestrand-Trimingham area were inaccessible at the time due to the existence of a minefield. In recent years, the biostratigraphy and palaeoecology of the Sidestrand Unio Bed has been reinvestigated by Preece \& Parfitt (2000), Preece (2001) and Preece et al. (2008) and assigned to the early Middle Pleistocene 'Cromerian Complex'. Research at nearby Overstrand and Trimingham (Figure 1a), has shown similar organic beds to be over- and underlain by a complex sequence of fluvial and marine sands and gravels (Green \& McGregor, 1990; Briant et al., 1999), punctuated in places by ice wedge casts (Fish et al., 1998; Whiteman, 2002).

From a wider perspective, during the Early and early Middle Pleistocene, north Norfolk occupied the northern part of an extensive coastal plain that was drained by a number of major river systems including the Ancestral Thames, Bytham and 'northern rivers' that extended eastwards into the North Sea from central England (Fig. 1b) (Allen \& Keen, 2000; Rose et al., 2001; Lee et al., 2006). Marine and coastal deposits correspond to the Norwich Crag (NCF) and the Wroxham Crag (WCF) formations, and these crop-out extensively throughout Norfolk and Suffolk where they interdigitate with river terrace sequences associated with the ancient Thames (Kesgrave Group) and Bytham river systems (Rose et al., 1999a,b, 2001, 2002). The complex geometry of these deposits reflects multiple episodes of sea-level change and fluvial aggradation / incision driven by neotectonic and eustatic processes (Whiteman \& Rose, 1992; Lewis, 1993 Rose et al., 1999a, 2001, 2002; Lee et al., 2006).

The switch in deposition from the NCF to the WCF corresponds to the increased influence of the 100ka (eccentricity) Milankovitch climate signal during the Early Pleistocene. This acted to enhance terrestrial processes resulting in river catchments extending westwards and transporting progressively more far-travelled materials, over 
Published in Proceedings of the Geologist's Association, 2009, Volume 120, pages 34-48.

longer distances, and more quickly into the coastal areas of the North Sea (Rose et al., 2001;

Lee et al., 2006). The WCF has been subdivided into three members based upon

sedimentology and lithology - the Dobb's Plantation and How Hill members, and in north Norfolk, the Mundesley Member (Rose et al., 2001). Sediment input into the Mundesley Member was from a series of 'northern river(s)' that were separate, and located to the north of, the Bytham catchment (Rose et al., 2001) - the alluvial sediments of these northern rivers correspond to the Cromer Forest-bed Formation. The first glaciation of the region laid-down the Happisburgh Formation (Lee et al., 2004b). Previously workers considered these deposits formed the basal till facies of the Anglian-age 'North Sea Drift' and were widely considered to have been deposited by Scandinavian ice (Perrin et al., 1979; Bowen et al., 1986; Ehlers \& Gibbard, 1991). Recent research has suggested the Happisburgh Formation to have been deposited by British ice (Lee et al., 2002) during a pre-Anglian glaciation (Hamblin et al., 2000, 2005; Lee et al., 2004b) although this later assertion is currently the subject of much debate (Banham et al., 2001; Preece, 2001).

\section{METHODOLOGY}

Sections were chosen to demonstrate the geometry of the Sidestrand sequence. Individual sections were logged with observations made regarding geometry, sediment colour (Munsell Color value), texture, sedimentary and tectonic structure, and the nature of upper and low unit boundaries. The orientations of bedding and tectonic structures were recorded using a compass clinometer, and measurements plotted on equal area, lower hemisphere stereographic projections. The stratigraphic relationships of various tectonic elements were defined by examining their cross-cutting relationships, with different tectonic events denoted using standard structural nomenclature (e.g. D1, D2....Dn).

Bulk samples of sediment were collected for particle size and lithological analyses. Particle size distributions were determined using a combination of wet and dry sieving

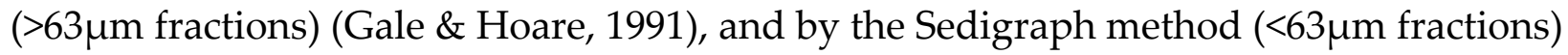
(Coakley \& Syvitski, 1991). Clast lithological analysis and heavy mineral analysis were utilised to aid sediment provenancing and stratigraphic correlation. Clasts were derived from bulk samples collected for particle size analysis, with pebbles within the $8-16 \mathrm{~mm}$ and 
Published in Proceedings of the Geologist's Association, 2009, Volume 120, pages 34-48.

16-32mm size fractions counted to enable comparison with regional datasets. Clast identification was aided using dilute hydrochloric acid and a low-powered binocular microscope. Heavy minerals were derived from bulk samples analysed for particle size analysis. Heavy mineral separation was performed following standard procedures (Gale \& Hoare, 1991), and counts were performed on the $63-125 \mu \mathrm{m}$ fine sand fraction to perform uniform observations condition and reduce the effects of hydraulic sorting. Minerals were identified by their optical properties in plain (PPL) and cross-polarised light (XPL) under a standard petrological microscope.

\section{DESCRIPTION AND INTERPRETATION OF UNITS}

Sedimentary logs for each of the eight logged sections are shown in Figure 2. Particle size data (Table 2), clast lithological (Table 3) and heavy mineral (Table 4) counts are shown in accompanying tables.

\section{Unit A}

Unit A crops-out at the base of the northern end of the section at Sites $\mathrm{S}$ and $\mathrm{T}$ although its base is obscured by modern beach material. The unit consists of crudely cross-stratified to massive ferruginous clast-supported gravel. Flint is the dominant clast lithology (65.0\%) with white (33.8\%) and brown (19.0\%) colours predominant. Quartzose lithologies are common, comprising $28.3 \%$ of the clast population, with white and colourless vein quartz being especially prevalent. Rhaxella chert, Carboniferous chert and 'Millstone Grit' sandstone are present as minor clast constituents, whilst crystalline erratics included schist, greywacke and porphyrytic basalt.

Cross-bedded and massive gravels are interpreted as being deposited by the migration of subaqueous gravel bars under a high flow regime.

\section{Unit B}

Unit B is between $0.2-0.4 \mathrm{~m}$ thick and consists of a pale yellow (2.5Y 7/4) to olive yellow (2.5Y 6/8) sand, matrix-supported ferruginous gravely sand and sandy gravel. It was recorded at all sites except Site $\mathrm{W}$ where it unconformably overlies Unit A. The contact 
Published in Proceedings of the Geologist's Association, 2009, Volume 120, pages 34-48.

between Units A and B was sharp, undulatory and erosional, commonly exhibiting a lag with occasional rip-up clasts of clay. Structurally the unit exhibits massive, planar and trough cross-bedding with comminuted shell debris within the foresets. No molluscs in life position were observed.

Analysed clast samples show a similar range and dominance of flint (57.3-68.1\%), vein quartz (21.4-33.2\%) and quartzite (3.8-7.2\%) clasts. White (23.9-35.9\%) and brown (12.6-19.4\%) flint types predominate, and white and colourless species dominate the quartzose fractions. Jurassic sandstones are present in higher proportions than Unit A Rhaxella chert (0.2-0.4\%) and ironstone being present in all four samples, and soft limestone (Lower Lias) present in three of the four samples. Carboniferous chert is present in all four samples in varying proportions (0.2-1.3\%) and Carboniferous 'Millstone Grit' sandstone is present $(0.4-0.7 \%)$ in two of the samples. Crystalline lithologies are present in all four samples (0.6-1.0\%) albeit in lower concentrations than Unit A - lithologies include schist, dolerite and granodiorite.

The irregular nature of the contact of Units A/B is interpreted as an erosional scour feature. The massive and cross-bedded gravels are interpreted as the scour fill associated with the down-current migration subaqueous gravel bars.

\section{Unit C}

Unit C was observed at Sites T, U and X where it occupies broad (2.3m), shallow $(0.4 \mathrm{~m})$ channels incised into Unit B (Figure 3a). The base of the channel is marked by a flint-rich gravel lag, which passes upwards into a thinly-bedded, stiff, dark bluish grey (2 GLEY 3/1) clay with frequent Unio shells identified by Preece \& Parfitt (2000) as Unio pictorum and Unio crassus.

The sedimentology of Unit C indicates an overall switch in the mode of deposition from channel incision and bar migration under relatively high flow regimes, to a lower flow regime and fine-grained sediment accumulation. The geometry of Unit C coupled with the basal gravel lag is interpreted as representing a small, shallow channel scoured into Unit B. The fining-up sequence comprising the lower gravel lag and upper thinlybedded clays indicates a switch from moderate-high energy bedload transport to 
Published in Proceedings of the Geologist's Association, 2009, Volume 120, pages 34-48.

suspension settling within a low energy environment. The presence of Unio pictorum and Unio crassus are diagnostic of a low energy fluvial depositional setting.

\section{Unit D}

Unit D crops-out at all sites where it rests upon units B or C. The maximum observed thickness of the unit is $0.25 \mathrm{~m}$. It consists of laminated dark grey (5Y 4/1) sandy silt with individual sets ranging in thickness from 4 to $12 \mathrm{~mm}$. Generally the lamination is horizontal. However at Sites W, Y and Z, the stratification is convolute in nature.

Horizontal-bedded sandy silts characterise deposition from high-density subaqueous bedload flows whilst convolute bedding is produced by differential liquefaction of sediment layers through rapid sediment burial (McKee \& Goldberg (1969). The association of the sedimentary evidence indicates that Unit D was deposited rapidly in a subaqueous environment with a high and pulsed fine-grained sediment input.

\section{Unit E}

Unit E rests conformably upon Unit D along the entire length of the section and is typically between 0.20 and $0.35 \mathrm{~m}$ thick. It consists of horizontal beds of dark grey (5Y 4/1) massive clayey silt - individual beds ranging between 0.08 and $0.16 \mathrm{~m}$ thick. Occasional desiccation cracks were noted penetrating down from bedding planes at Sites S and X. At the southern end of Site S, unit E is truncated by a distinctive, and slightly undulating, fracture that dips northwards at $11^{\circ}$ (Figure $3 b$ ) before cutting-out along a bedding plane.

Horizontal beds of massive clayey silt record high rates of deposition from suspension-settling under a low flow regime with bedding surfaces representing hiatuses in deposition. Mud cracks relate to drying and shrinkage during subaerial exposure and demonstrate the cyclic exposure / burial of a land surface and a relative fall in water level from Unit D.

\section{Unit F}

At sites $\mathrm{V}, \mathrm{X}$ and $\mathrm{Y}$, unit $\mathrm{F}$ infills small channel structures cut into Unit E. These channels range in width between 1.3 and $3.1 \mathrm{~m}$, and depth 0.3 and $0.5 \mathrm{~m}$. The bases of the channels 
Published in Proceedings of the Geologist's Association, 2009, Volume 120, pages 34-48.

have an irregular and undulating morphology, typically exhibiting a coarse lag of clayey rip-up clasts. This basal lag grades upwards into a mélange of crudely-stratified inter-beds of dark greyish brown (2.5Y 4/2) silty fine sand with occasional muddy flasers, and greyish brown (2.5Y 4/2) clayey silt. Convolute bedding is common within the sandier beds.

The sedimentology of Unit F and its geometric relationship to underlying Unit $\mathrm{E}$ demonstrate that it forms a vertical and lateral succession of small channels and associated fills. The occurrence of a coarse lag consisting of rip-up clasts indicates local scouring along the base of the channels. Crudely stratified inter-beds of silty fine sand and clayey silt reveal frequent changes in subaqueous energy regime from moderate to low energy, and the mode of settling from bedload to suspension settling. The mélange of silty sand and clayey silt, with occasional convolute bedding, is interpreted as loading-induced dewatering associated with high rates of subaqueous sedimentation.

\section{Unit G}

Unit G rests conformably upon the upper surface of Units E and / or F at Sites T, U, V, W, $\mathrm{X}$ and $\mathrm{Y}$. Its base is irregular and gently undulatory in geometry and often marked by a thin clay pebble lag. The unit ranges in thickness from 0.2 to $0.4 \mathrm{~m}$ and consists of longitudinal cross-bedding that dips gently $\left(3-5^{\circ}\right)$ towards the northeast. Individual sets within the longitudinal cross-bedding consist of laminated silty fine sand and clayey sand, wavy bedding and lenticular bedding. Small intra-formational normal faults were observed at Sites T and Y, striking broadly northwest-southeast which down-throw to the north.

The irregular basal geometry and existence of a thin clay pebble lag are consistent with erosive scouring. The presence of longitudinal cross-bedding is characteristic of lateral erosion and accretion within a channel where strike of the bedding lies parallel to the current direction. Normal faulting corresponds to localised collapse within the channel sides perhaps during drying or by active undercutting. Individual sets consisting of laminated silty fine sand and clayey sand, wavy bedding and lenticular bedding, record subtle fluctuations in both energy regime and sediment supply. 


\section{Unit H}

Unit $\mathrm{H}$, upto $0.5 \mathrm{~m}$ thick, was observed at Site $\mathrm{U}$ and could be traced towards the southeast before being obscured by talus, to the northeast it is truncated by Unit I. The unit is composed of thin beds of light yellowish brown (2.5Y 6/4) horizontal and rippled (type-A) fine sand, (medium-grained) hummocky cross-stratified sand (HCS), that pass upwards into coarsely interlayered beds of light yellowish brown (2.5Y 6/3) sand and dark olive brown (2.5Y 3/3) clayey silt. These beds are overlain by stratified pale yellow (2.5Y 7/4) sand and light yellowish brown (2.5Y 6/4) silty sand which exhibit convolute bedding. The contact between the clayey silts and the sands is highly irregular in morphology with wispy and flame-like tongues of clayey silt extending into the sand.

The upwards transition from horizontal and rippled sands to HCS to interlayered sands and clayey silts record significant switches in energy regime and sediment supply within a subaqueous depositional setting above the storm wave base. Horizontallybedded sands were laid-down subaqueously from high-density bedload flows, whilst type-A ripples record the downcurrent migration of sandy ripples under a lower flow regime. HCS is produced by wave-generated oscillatory flows or combined wave / current flows during storm events (Duke, 1985). Interlayered sands and clayey silts record more abrupt changes in sediment supply and energy regime from high-density bedload flows to suspension settling. The convolute bedding within the overlying beds of sand, coupled with the irregular, wispy and flame-like form of the contact with the interlayered sands and clayey silts implies sedimentation was rapid and the interstitial porewater content of all of the sediments was high.

\section{Unit I}

At site U, Unit I cuts through Unit H down into to Unit G before pinching out adjacent to Site $\mathrm{V}$. The unit consists of planar cross-bedded yellow (2.5Y 7/6) pebbly sand and associated olive brown (2.5Y 4/3) silty clay drapes with numerous reactivation surfaces, passing upwards into horizontally-bedded sand. The foresets dip towards the east and east-southeast, and reach a maximum observed height of $0.4 \mathrm{~m}$. 
Published in Proceedings of the Geologist's Association, 2009, Volume 120, pages 34-48.

Planar cross-bedded pebbly sands are produced by the down-current migration of straight-crested subaqueous dunes.

\section{Unit J}

Unit J crops-out along the entire length of the section where it variably overlies units E, F, $\mathrm{G}$ and I, and ranges in thickness from 0.8 to $1.7 \mathrm{~m}$. It consists of coarsely, interlayered beds of pale yellow (5Y 7/3) to light yellowish brown (2.5Y 6/4) horizontal and rippled sand and light olive brown (2/5Y 5/6) clayey silt that vary in relative thickness both laterally and vertically (Figure 3b). Thick clayey silt beds frequently exhibit wavy and lenticular bedding, and syn-depositional load structures were evident at Sites X and Z.

At several sites, Unit $\mathrm{J}$ is cross-cut by a number of gently-inclined $\left(7-13^{\circ}\right)$ to subhorizontal thrusts and sand-filled fractures that extend upwards through the sequence being truncated by Unit $\mathrm{M}$ and dip towards the north and northwest (Figure 4). The base of these structures can be observed at Sites S (Figure 3b) and Z where they lie along clayrich horizons within Unit J or Units E and F. At Site S, sediments on the 'hanging-wall' (Unit J) of a distinctive fracture that truncates Unit E (see also Unit E), exhibit convolute bedding.

The sedimentology of Unit J, characterised by interlayered beds of rippled sand and clayey silt of variable thicknesses record temporal and spatial changes in a subaqueous energy regime from moderate to low energy, and the mechanism of deposition from bedload to suspension settling. Wavy and lenticular beds form as a result of the generation of incomplete ripples and their burial by fine sediment in a depositional system with a limited coarse sediment supply (Reineck \& Wunderlich, 1968). Syn-depositional load structures are produced by the deposition (both blanket or differential) of coarse material over a semi-mobile hydroplastic layer rich in fine sediment.

The similar orientation of the sand-filled fractures and thrusts that deform Unit J suggests that the fractures were originally thrusts formed through the brittle response of the sediment pile to the application of shear stresses from the north and northwest. Following this brittle event, several of the thrusts were re-activated as hydrofractures forming the sand-filled fractures. In the majority of cases, water was constrained along the 
Published in Proceedings of the Geologist's Association, 2009, Volume 120, pages 34-48.

original thrust surface. However at Site S, water has re-saturated the hanging-wall block causing localised water-rich soft-sediment deformation.

\section{Unit K}

Unit K crops-out at Site W and consists of a $0.5 \mathrm{~m}$ thick mélange of stratified grey (5Y 5/1) silty sand. The length of the lens exceeds $6 \mathrm{~m}$ and its base is gently inclined (6-8 $\left.{ }^{\circ}\right)$ towards the north-northwest where it truncates in situ bedding within Unit J. The form of this base is variable - in places it is sharp and planar. However elsewhere, the boundary, although traceable, is diffuse and flame-like in appearance. The upper boundary of the unit is truncated by Unit L, whilst the northern end of the lens is obscured between Sites W and $\mathrm{V}$ by a large cliff fall. Internally the mélange exhibits a crude stratification although this has been deformed into a series of open to tight asymmetrical and disharmonic folds (Figure 3c). Bedding contacts with adjacent units are highly irregular and diffuse in nature, characterised by wispy and flame-like interdigitation, and attenuated inclusions of pale yellow (5Y 7/3) sand.

Sedimentological and structural evidence indicate a complex polyphase origin for Unit K. Stratified sandy silts imply that the primary mode of deposition was from dense sediment-laden bedload currents, with individual bedding surfaces representing pauses in deposition. Structural evidence, however, demonstrates that the unit has been remobilised following deposition due to the application of compressive stress. The inclined lower contact of the unit with Unit $\mathrm{J}$ is interpreted as a low angle thrust due to its often sharp and planar morphology and the inverted stratigraphy. However, the occasionally diffuse and wispy nature appearance of this thrust suggests that it has also been utilised, perhaps during deformation, as a pathway for the transportation of intergranular porewater. The internal contacts, presence of attenuated inclusions of sand and wispy and flame-like intercalated also lend support to the availability of porewater, and demonstrate that the deformation was ductile and controlled by the higher porewater content of the sandy silts relative to the adjacent sands. 


\section{Unit L}

Unit L was recorded at three sites - W, X and $\mathrm{Y}$ where it rests upon either Unit $\mathrm{K}$ (Site W) or Unit J (Sites $\mathrm{X}$ and $\mathrm{Y}$ ). At Site $\mathrm{X}$, the primary sedimentary features are undeformed, and reveal upto $0.3 \mathrm{~m}$ of cross-laminated (Type-A) and horizontally stratified, very pale brown (10YR 8/2), fine- to medium-grained sand and sandy silt. At Site $X$ the unit forms a contorted mélange of silty sand with convolute bedding, disharmonic fold structures and wispy laminae contacts. This deformation truncates the thrust which forms the base of Unit $\mathrm{K}$ and the internal deformation within Unit $\mathrm{K}$ itself, and is in-turn truncated by the plane of décollement that forms the base of Unit M.

Type-A cross-laminated sands are interpreted as representing the down-current migration of subaqueous ripples under relatively low rates of sedimentation, whilst horizontal sands record episodes of rapid deposition from bedload transport. Convolute bedding, disharmonic folds and wispy laminae are the product of shear-induced shortening and ductile deformation within water-rich sediment. Cross-cutting relationships between tectonic structures within and adjacent to Unit L demonstrate that the soft-sediment deformation post-dates tectonised sediments within Unit K. Unit L deformation is in-turn cross-cut by the décollement plane at the base of Unit M indicating that it predates this deformation event.

\section{Unit M}

Unit M crops-out discontinuously along the length of the cliff section and was logged at Sites S, U, V, Y and Z where it has a sharp and irregular basal contact truncating Units J and L. The unit ranges in thickness between $0.2-0.4 \mathrm{~m}$ and exhibits a similar lithology to Unit C. It consists of a variable sandy, sandy clay and clayey lithology, containing Unio shells within either a dark grey (5Y 3/1) pebbly (flint) clay or a grey (5Y 4/1) weakly stratified silty sand. From a structural perspective, throughout much of the unit stratification is very poorly defined or entirely absent with lithologies exhibiting a near homogenised state. Elsewhere within the unit isolated 'rafts' of stratified materials frequently exhibit disharmonic folding and / or flame-like contacts with the matrix. At Site $\mathrm{U}$, a mass of sand from underlying Unit L, has been detached and incorporated into Unit 
Published in Proceedings of the Geologist's Association, 2009, Volume 120, pages 34-48.

$\mathrm{M}$ as a series of tight, gently-inclined, asymmetrical fold structures that verge towards the south. An undeformed Unio valve was noted within one of the fold structures (Figure 3d). Unit M has a highly complex nature. The largely homogenous diffuse structure of the unit, coupled with the evidence for folding, flame structures and the preservation of the Unio shells all point to water-rich soft-sediment ductile deformation in response to the application of shear stress.

\section{Unit N}

Unit $\mathrm{N}$ caps the succession along the entire length of the coastal section. It is upto $3 \mathrm{~m}$ thick and consists of a massive, highly consolidated, dark grey (10YR 4/1) to grey $(2.5 \mathrm{Y} 5 / 1)$ matrix-supported diamicton that exhibits a sandy clay matrix texture. Clasts are rare and with flint, vein quartz, quartzite and shell debris predominating; minor proportions of fartravelled lithologies such as alkali granite, granodiorite, dolerite, quartz schist, greywacke, Old Red Sandstone were also recorded. The base of the diamicton is generally sharp and sub-horizontal in geometry although adjacent to Site $\mathrm{U}$, 'inclusions' of Unit $\mathrm{M}$ have been incorporated into the base of the diamicton (Figure 3d). These 'inclusions', sub-horizontal in inclination, have the form of attenuated foliations, boudins, and overturned fold structures where part of the upper limb has been detached and removed along a low angle thrust plane.

Based upon its sharp basal plane of décollement, massive and highly consolidated appearance, and the admixture of local and far-travelled lithologies, Unit $\mathrm{N}$ is interpreted as a subglacial till (Hart \& Boulton, 1991; Hart \& Roberts, 1994; Benn \& Evans, 1996). Inclusions of Unit M material within Unit $\mathrm{N}$ indicate that shear stress was transported through parts of the pre-existing sediment pile, and accommodated with a variable ductile (overturned fold structures), brittle (thrusts) and ductile-brittle (attenuated lineationsboudinage) response of the deformed lithologies. The evolution of this subglacial shear zone is discussed further below.

\section{PROVENANCE OF LITHOLOGIES}


Published in Proceedings of the Geologist's Association, 2009, Volume 120, pages 34-48.

Clast lithologies and heavy minerals are powerful lithological proxies during the Early and early Middle Pleistocene of central and eastern England, and can be used to aid stratigraphic correlation and reconstruct sediment provenances (Figure 5).

'Fresh' black flint is derived from flint horizons within Chalk (Upper Cretaceous) strata within eastern England. 'Recycled' flint includes white, brown and chatter-marked forms, which have undergone multiple episodes of surface weathering and recycling processes during the Cenozoic (Whiteman \& Rose, 1992). Red / brown quartzose clasts can be provenance to the 'Bunter' conglomerates of the Sherwood Sandstone Formation (Triassic) of central England. White or colourless quartzose clasts relate to either bleached ‘Bunters' recycled from older Quaternary deposits (Hey, 1976), or from coarse conglomerates within the 'Millstone Grit' (Carboniferous) of the Pennines. Other persistent lithologies include Greensand chert and Spilsby (glauconitic) Sandstone from the Lower Cretaceous of southern England and Lincolnshire respectively; Rhaxella chert and Lias Limestone from the Jurassic of Yorkshire; crinoidal chert and immature Millstone Grit sandstone from the Carboniferous of Yorkshire. Far-travelled crystalline and sedimentary erratics are also present in East Anglia. These include acid volcanic rocks such as tuff, rhyolite and green porphyry from North Wales (Hey and Brenchley, 1977; Whiteman and Rose, 1992), and Old Red Sandstone and porphyrytic basalt from the Midland Valley of Scotland, greywacke from the Southern Uplands, dolerite from the Tertiary intrusions of Northern England and Central Scotland (e.g. Whin Sill), and schist either reworked from Old Red Sandstone conglomerates within the Midland Valley of Scotland, or derived from their primary source within Central Scotland (Lee et al., 2002, 2006).

Heavy minerals are also valuable in provenancing sediments in central and eastern England (Lee et al., 2006). Zircon and garnet are residual 'Crag' minerals during the Early and early Middle Pleistocene (Lee et al., 2006). Resistant minerals are derived from Mesozoic strata within Central England with inputs of zircon, tourmaline, kyanite and staurolite from Triassic (Bateman \& Rose, 1994), rutile from Carboniferous (Bateman \& Rose, 1994), and collophane (cryptocrystalline apatite) from phosphatic nodular horizons within Jurassic and Lower Cretaceous rocks in eastern England (Lee et al., 2004b). 
Published in Proceedings of the Geologist's Association, 2009, Volume 120, pages 34-48.

Amphibole, epidote, pyroxene and apatite (monocrystalline-type) are derived from igneous rocks and low- to medium-grade metamorphic terrains within southern and central Scotland, and from the recycling of Eocene sediments in the North Sea (Perrin et al., 1979; Lee et al., 2004b).

Associations of heavy minerals and clast lithologies can be used to link lithological composition to lithostratigraphic assemblages and sediment derivation from particular river systems (Lewis, 1993; Rose et al., 1999a, b, 2001; Lee et al., 2004b, 2006). Sediments derived from both the 'northern river(s)' and Bytham river catchments contain a similar assemblage of clast lithologies and heavy minerals derived largely from Carboniferous, Triassic and Jurassic in Central England - quartzose clasts, Carboniferous chert, Millstone Grit and Spilsby Sandstone (Rose, 1987; Lewis, 1993; Rose et al., 1999a), Lias (Lower Jurassic) limestone, and high concentrations of zircon, rutile, staurolite, kynaite, tourmaline and collophane (Bateman \& Rose, 1994; Lee et al., 2004b). The key discriminating of a 'northern river(s)' input is Rhaxella chert as its primary source is in North Yorkshire (Green \& McGregor, 1990; Rose et al., 1996, 2001). Lithological input from the Thames is characterised by Triassic quartzose clasts (mainly colourless), Greensand chert and Welsh volcanic rocks (Whiteman and Rose, 1992; Rose et al., 1999b). Elevated levels of residual zircon and garnet are indicators of shallow marine 'Crag' sedimentation (Lee et al., 2006), whilst far-travelled erratics and heavy minerals including amphibole, epidote and pyroxene are diagnostic of either a direct, or indirect glacial source (Lee et al., 2004b, 2006).

\section{DISCUSSION}

\section{Lithostratigraphy and palaeoenvironmental reconstruction}

In this section, units within the Sidestrand succession are placed into the regional lithostratigraphy and palaeoenvironments reconstructed (Table 5).

Units A-L record patterns of sedimentation within an actively aggrading estuarinefluvial depositional setting. The sedimentology of Units A and B could relate to the migrate of gravel bars within either a braided river channel or a shallow marine environment. However, the lithology of these units, represented by elevated proportions 
Published in Proceedings of the Geologist's Association, 2009, Volume 120, pages 34-48.

of garnet, glauconite and zircon are more characteristic of shallow marine deposits within the region (Figure 6; Lee et al., 2006). Therefore, Units A and B are suggested to be part of the Mundesley Member of the WCF, and the weakly stratified sandy gravels separated by an erosional surface with rip-up clasts were probably represent scouring and infilling of a tidal channel located within the outer, seaward margins of an estuary (Reinson, 1992). Significantly the presence of Rhaxella chert, Lias limestone and Millstone Grit in WCF (marine), indicate the close proximity of Sidestrand to a river system draining Lower Jurassic and Carboniferous bedrock in Central England. The presence of Rhaxella chert derived from north Yorkshire, demonstrate the existence of the 'northern river' close to Sidestrand.

The predominance of resistant heavy mineral species within Unit C, such as kyanite, rutile, tourmaline, staurolite plus collophane, are characteristic of a direct fluvial sediment input from a river system draining Mesozoic sediments within Central England (Bateman \& Rose, 1994; Lee et al., 2004b) with minimal marine dilution (Lee et al., 2006) (Figure 6). A fluvial interpretation of this unit, known as the Sidestrand Unio Bed of the Cromer Forest-bed Formation (CFbF) (Preece \& Parfitt, 2000), is further supported by the presence of freshwater molluscs Unio pictorum and Unio crassus (Preece \& Parfitt, 2000; Preece, 2001). Fluvial deposits of the CFbF, including the Sidestrand Unio Bed described within this study and the West Runton Freshwater Bed at West Runton, are likely to be directly related to this river system.

The sedimentology and lithology of Units A-C at Sidestrand form part of an overall regressive cycle and the transition from marine to terrestrial deposition. The absence of intervening inner-estuarine deposits between the outer estuary (Units A and B) and low energy fluvial (Unit C) deposits suggests that an unconformity exists between Units B and C.

High proportions of garnet, glauconite and zircon coupled with their sedimentology enable Units D-L to also be identified as the Mundesley Member of the WCF (Figure 6). Units E and F could be either lagoonal or alluvial in origin, based upon their fine grained texture and the presence of desiccation cracks, although the presence of muddy flasers, characteristic of a tidal current activity, suggests that a lagoonal setting is 
Published in Proceedings of the Geologist's Association, 2009, Volume 120, pages 34-48.

more likely (Reineck \& Wunderlich, 1968). Channels and associated fills, including basal rip-up lag (Unit F), are typical of a tidal channel-fill, whilst longitudinal cross-bedding (Unit G) is produced by the lateral shifting of point bars within tidal channels on intertidal flats (Reineck, 1968). Unit H consists of tidal rhythmites - typical of tidal flat sedimentation (Mazumder \& Arima, 2005), whilst the horizontal and rippled sands plus the HCS are produced during higher energy storm events (Duke, 1985). Unit I is interpreted as being deposited as a series of prograding sand bars based upon the horizontal and cross-bedding and numerous reactivation surfaces. Clay drapes characterise periods of low energy deposition that are formed during ebb tidal patterns. However the bulk sandy texture suggests a lateral facies shift probably into a more proximal position relative to the estuary mouth (Komatsu, 1999). Tidal-flat sedimentation is indicated by tidal rhythmites (Unit J), however the absence of HCS, recognised earlier within Unit H, suggests sedimentation in deeper water beneath the storm wave-base. Cross-laminated and horizontally-bedded sands record bedload transport and ripple migration under a moderate flow regime (Unit L). Units E-L (WCF), therefore, record shifting patterns of tidal-flat and estuarine sedimentation during a transgression. This reflects either a sea-level rise, or more likely, a lateral facies shift from deposition within tidal flats into deeper water parts of the tidal estuary (Komatsu, 1999).

Units $\mathrm{K}, \mathrm{M}$ and $\mathrm{N}$ are interpreted as a glacigenic assemblage produced by the subglacial accretion and deformation of a pre-existing sediment pile (Hart \& Boulton, 1991; Hart \& Roberts, 1994; Benn \& Evans, 1996). Units K and M are tectonites of this glacigenic assemblage (cf. Banham, 1977) derived from the remobilisation and partial mixing of various preglacial lithologies during shearing (Hart et al., 1990). Unit $\mathrm{N}$ is interpreted as a subglacial deformation till based upon its high consolidation, sharp basal décollement and mixture of local- and far-travelled lithologies (Hart \& Roberts, 1994). The grey colouration, sandy clay matrix texture and flint-rich clast assemblage identify this till as the Happisburgh Till Member of the Happisburgh Formation (Lee et al., 2004a). This till was laid-down during the first advance of British ice into the region during the Middle Pleistocene (Lee et al., 2002). Kinematic indicators including folds, thrusts and fractures associated with the accretion of the till indicate an ice advance from the north and 
Published in Proceedings of the Geologist's Association, 2009, Volume 120, pages 34-48.

northwest, which is consistent with other structural observations from elsewhere in north Norfolk (Hart, 1987; Lee, 2001). The evolution of this subglacial shear zone is examined further in the next section.

\section{Evolution of the subglacial shear zone}

In this section, the evolution of the subglacial shear zone that developed in association with the southerly ice advance and deposition of the Happisburgh Till Member are examined. Shear stresses resulted in glaciotectonic deformation and partial remobilisation of the pre-existing sediment pile. Four different stages of glaciotectonic deformation (D1D4) can be recognised based on the cross-cutting relationship of different structural and stratigraphic elements within Units K-N (Figure 7).

During D1, shear stresses within the sediment pile were accommodated by an initial stage of brittle deformation (D1i) associated with the emplacement of Unit K along a low angle thrust. Movement and transport along the thrust was accommodated by ductile deformation within the hanging-wall block (Unit K) and the formation of open and disharmonic folds and wispy and flame-like contacts between laminae (D1ii). D2 truncates the D1i thrust and is represented by structural elements within Unit L that characterise ductile soft sediment deformation (e.g. convolute bedding, disharmonic folding and wispy laminae contacts). In-turn, D2 is truncated by a second phase of brittle deformation (D3) associated with large-scale thrusting that propagate through the preglacial sediment pile and the transportation of 'hybrid' Unit M.

During D3, Unit $\mathrm{M}$ was generated through glaciotectonic mixing of older preglacial sediments. Evidence for this mixing includes the highly contorted and diverse range of lithologies present within Unit M plus the diffuse heavy mineral composition that is broadly intermediate between 'fluvial' and 'marine' assemblages (Figure 6). Significantly, Unit M contains abundant Unio shells which are presumably derived from Unit C (or spatial equivalent) towards the base of the succession - the preservation of these fragile is discussed in the following section. The most logical explanation for the higher stratigraphic occurrence is that in places, parts of Unit C have been transported 'upstratigraphy' by low-angle subglacial thrusting (cf. Lee \& Phillips, 2008), in a similar 
Published in Proceedings of the Geologist's Association, 2009, Volume 120, pages 34-48.

manner to the emplacement of Unit K during D1i. During thrusting, these 'rafts' have assimilated and mixed with elements of surrounding preglacial sediment and have then become detached from their thrusts and partially entrained within the higher strain zones within the deforming bed.

The final deformation event (D4) includes the dewatering of the lower horizons of the deformable bed via D3 thrusts being reactivated as drainage conduits (i.e. hydrofractures) (D4i). D4ii coincides with the incorporation of Unit M into Unit $\mathrm{N}$ via variably ductile (overturned fold structures), brittle (thrusts) and ductile-brittle (attenuated lineations-boudinage) deformation within the highest strain zones of the deforming bed.

Deformation through events D1-D4 exhibits elements of both the 'mosaic' (c.f. Piotrowski and Krauss, 1997; Hoffman \& Piotrowski, 2001; Piotrowksi et al., 2004) and 'pervasive' (c.f. van der Meer et al., 2003; Menzies et al., 2006) subglacial deforming bed models. A hybrid model to explain this style of subglacial deformation was presented by Lee and Phillips (2008) whereby zones of lower and higher strain (and therefore deformation) were partitioned by rheology and temporal / spatial variations in porewater content. At Sidestrand, relatively higher strain areas towards the top of the deforming bed profile are shown by the variable ductile-brittle rheological response (D4ii) of deforming materials. In the deeper, relatively lower strain areas of the deforming bed profile, deformation D1-D3 are driven by temporal and spatial fluctuations in intergranular porewater content. These changes in the water content within the subglacial sediment pile probably developed in response to the overburden pressure exerted by the overriding ice, sediment dilation, and by tectonic thickening and accretion of the deforming bed (Lee and Phillips, 2008). Several of the thrust faults that propagate through the Sidestrand preglacial sediment pile may have been reactivated as hydrofractures to accommodate localised drainage within the deforming bed (D4i).

\section{Preservation of fragile bioclasts}

One of the interesting features of the subglacially tectonised sediments is the preservation of fragile Unio shells. Fragile fossils have been widely recognised within other subglacial 
Published in Proceedings of the Geologist's Association, 2009, Volume 120, pages 34-48.

tills (e.g. Hicock and Driemanis, 1992; Ó Cofaigh and Evans, 2001), however the precise mechanism of their preservation is controversial (Piotrowski et al., 2004). Piotrowski et al. (2004) highlight the apparent contradiction within the pervasive deforming bed model between the occurrence of dilatant sediments indicative of lower strain and low intergranular contacts that have acted to preserve fragile fossils / rocks, and the presence of highly abraded erratic clasts diagnostic of higher strains.

Structural evidence presented here illustrates that Unit $\mathrm{M}$ was emplaced upsequence along thrust planes, before being partially incorporated into the overlying Happisburgh Till Member as a series of detached fold structures. This demonstrates that strain was being transmitted into Unit M adjacent to a major rheological boundary (i.e. base of Unit N). However, the abundance of soft-sediment deformation structures within Unit $\mathrm{M}$ implies that shear stresses beneath this discontinuity were being largely accommodated by elevated inter-granular porewater content that followed sediment dilation resulting in low effective pressures. The overall lack of homogenisation and breakdown of the fragile fossils can thus be explained by the fact that materials with high fluid contents are less able to transmit stress into the groundmass than 'drier' more competent material, coupled with a short transportation distance. Effectively this means that structures typically associated with higher strain regimes (e.g. augens; cf. Hart \& Boulton, 1991; Benn \& Evans, 1996) can be produced under relatively low shear stresses as a consequence of elevated porewater pressures and low effective pressures (Boulton et al., 1974). Temporal and spatial fluctuations of porewater content, coupled with the partitioning of deformation into discrete horizons within tills and glaciotectonised sediments can therefore act to preserve fragile lithologies.

\section{Chronology and Environmental Change}

Sidestrand is a key site in unravelling the chronology of environmental change and glaciation within lowland Britain during the Middle Pleistocene (Preece, 2001; Lee et al., 2004b, Preece et al., 2008). The key stratigraphic unit at Sidestrand is the Sidestrand Unio Bed (Unit C) which is dated to one of the early Bruhnes interglacials within the 'Cromerian 
Published in Proceedings of the Geologist's Association, 2009, Volume 120, pages 34-48.

Complex' based upon normal palaeomagnetism, and molluscan and microtine rodent faunas (Preece \& Parfitt, 2000).

Wroxham Crag Formation sediments (Units D-L) that overlie the Sidestrand Unio Bed can, therefore, be placed within the 'Cromerian Complex' although their precise age remains unclear. A regressive (Units A-C) and transgressive (Units E-L) cycle can be identified within these deposits. This could reflect eustatic change at a Milankovitch or sub-Milankovitch time-scale superimposed upon successive cooling and warming trends, however equally, these facies changes could simply reflect local changes in patterns of sedimentation and palaeogeography within an actively accreting tidal flat environment.

The precise age of the Sidestrand Unio Bed is a contentious issue with relevance to the age of the Happisburgh Till Member and the first lowland glaciation within eastern England (Hamblin et al., 2000, 2005; Banham et al., 2001; Lee et al., 2004b; Preece et al., 2008). Previously the Happisburgh Till Member was considered to have been deposited during the Anglian Glaciation (MIS 12) (Bowen et al., 1986; Bowen, 1999), however recent studies reveal that the till can be separated from Anglian deposits by a number of temperate indicators that are representative of at least one temperate climate episode. Evidence includes the presence of intervening shallow marine deposits (Lee et al., 2006) that contain a fully-temperate fauna (Read et al., 2007), and a temperate palaeosol equivalent to the Valley Farm Soil (J Rose, unpublished data). An MIS 16 age has been tentatively suggested for the age of the Happisburgh Till based upon the correlation of the till sequence with the terrace chronology of the Bytham River, and modelling of patterns of river terrace aggradation and incision to global climate forcing (Lee et al., 2004b). Whilst this age determination coincides with evidence for widespread ice expansions elsewhere in Europe (Ehlers and Gibbard, 2007), a MIS 16 age is currently incompatible with chronologies for the 'Cromerian Complex' based upon biostratigraphic and amino-acid relative age determinations. This evidence indicates that the Sidestrand Unio Bed relates to either MIS 15 or 13 implying that the overlying Happisburgh Till cannot be as old as MIS 16 and must relate to a younger glaciation (Preece et al., 2008). The precise age of the Sidestrand Unio Bed and therefore the first lowland glaciation of eastern England represented by the Happisburgh Till is a contentious subject. Whilst some have questioned 
Published in Proceedings of the Geologist's Association, 2009, Volume 120, pages 34-48.

the validity of applying river terrace chronologies to determining the age of the Happisburgh Till (Preece \& Parfitt, 2007; although see Rose, 2006), others have highlighted the empirical nature of the biostratigraphic record (Lee et al., 2004b) and the much-reduced reliability of amino-acid dating beyond MIS 12 (Preece et al., 2008).

Whilst this study does not contribute directly to the debate surrounding the age of the Sidestrand Unio Bed as it clearly underlies the Happisburgh Till, it does highlight a potential problem surrounding the relative stratigraphic position of the deposit - that 'Unio Bed' material occurs in several different stratigraphic positions. Of these, only the lower occurrence relating to Unit $C$ is in situ, its occurrence higher within the succession (Unit M) immediately beneath the Happisburgh Till is the result of subglacial glaciotectonic deformation. Critically within Unit M, Unio Bed material has been partially mixed with overlying lithologies as glaciotectonic rafts of the unit have been transported up-sequence by thrusting. This implies that accurate and reliable palaeoenvironmental or biostratigraphic data from the Unio Bed can only be gathered from Unit C.

\section{CONCLUSIONS}

- A complex sequence of early Middle Pleistocene preglacial and glacial units are described from coastal cliff sections at Sidestrand, north Norfolk. Preglacial units consist of estuarine and fluvial deposits that correspond to the Wroxham Crag and Cromer Forest-bed Formations, whilst glacial deposits equate to the Happisburgh Formation that were deposited during the first lowland glaciation of the region.

- Provenance analysis of clasts and heavy minerals within the preglacial deposits demonstrates the proximity of Sidestrand to a large river system that flowed over Mesozoic rocks in northern and central England.

- The Sidestrand Unio Bed, one of the most important biostratigraphic marker horizons within the Cromer Forest-bed Formation is diachronous cropping-out at both the base and top of the succession at Sidestrand. Only the lower facies is considered to be in situ, the upper facies being tectonic in origin, with material being remobilised along glaciotectonic thrust planes and partially mixed with adjacent estuarine sediments. 
Published in Proceedings of the Geologist's Association, 2009, Volume 120, pages 34-48.

Sedimentological, palaeoecological and biostratigraphic interpretations of material taken from this upper 'Unio bed' should be considered unreliable.

\section{Acknowledgements}

JRL wishes to thank Peter Balson, Nigel Larkin, Tony Morigi, Richard Preece and Jim Rose for discussing various aspects of this paper. Emrys Phillips, Becky Briant and Steven Pawley are thanked for their constructive reviews of the manuscript. The author publishes with the permission of the Executive Director of the British Geological Survey (NERC).

\section{References}

Allen, P., Keen, D.H. 2000. Uppermost Norwich Crag and Lower part of theCromer Forestbed Formations. In: Lewis, S.G., Whiteman, C.A., Preece, R.C. (eds). The Quaternary of Norfolk and Suffolk, Field Guide, Quaternary Research Association, London, 29-34.

Banham, P.H. 1968. A preliminary note on the Pleistocene stratigraphy of north-east Norfolk. Proceedings of the Geologists' Association, 79, 469-474.

Banham, P.H. 1977. Glaciotectonites in till stratigraphy. Boreas, 6, 101-105.

Banham, P.H. Gibbard, P.L., Lunkka, J.P., Parfitt, S.A., Preece, R.C., Turner, C. 2001. A critical assessment of 'A new glacial stratigraphy for Eastern England'. Quaternary Newsletter, 93, 5-14.

Bateman, R.M., Rose, J. 1994. Fine sand mineralogy of the Early and Middle Pleistocene Bytham Sands and Gravels of Midland England and East Anglia. Proceedings of the Geologists' Association, 105, 33-39.

Benn, D., Evans, D.J.A. 1996. The interpretation and classification of subglacially deformed materials. Quaternary Science Reviews, 15, 23-52. 
Published in Proceedings of the Geologist's Association, 2009, Volume 120, pages 34-48.

Boulton, G.S., Dent, D.L., Morris, E.M. 1974. Subglacial shearing and crushing, and the role of water pressures in tills from south-east Iceland. Geografiska Annaler, 56A, 135-145

Bowen, D.Q., Rose, J., McCabe, A.M., Sutherland, D.G. 1986. Quaternary Glaciations in England, Ireland, Scotland, and Wales. Quaternary Science Reviews, 5, 299-340.

Bowen, D.Q (ed.) 1999. A revised correlation of Quaternary deposits in the British Isles. Geological Society of London Special Report No. 23.

Briant, R.M., Rose, J., Branch, N.P., Lee, J.A. 1999. ‘Pre-glacial' Quaternary sediments from Trimingham, north Norfolk, England. Bulletin of the Geological Society of Norfolk, 49, 15-47.

Coakley, J.P., Syvitski, J.P.M. 1991. Sedigraph technique. In: Syvitski, J.P.M. (ed.)

Principles, methods and application of particle size analysis. Cambridge University Press, Cambridge.

Duke, W.L. 1985. Hummocky cross-stratification, tropical hurricanes, and intense winter storms. Sedimentology, 32, 167-194.

Ehlers,J., Gibbard, P.L. 1991. Anglian glacial deposits in Britain and the adjoining offshore regions. In: Ehlers, J., Gibbard, P. L., Rose, J. (eds). Glacial Deposits of Great Britain and Ireland, Balkema, Rotterdam, 17-24.

Fish, P.R., Carr, S.J., Rose, J., Hamblin, R.J.O., Eissmann, L. 1998. A periglacial compositewedge cast from the Trimingham area, North Norfolk, England. Bulletin of the Geological Society of Norfolk, 46, 11-16.

Funnell, B.M. 1995. Global sea-level and the (pen-) insularity of late Cenozoic Britain. In: Preece, R.C. (ed.). Island Britain: a Quaternary perspective. Geological Society Special Publication No 96, pp 3-13. 
Gale, S.J., Hoare, P.G. 1991. Quaternary sediments: petrographic methods for the study of unlithified rocks. Wiley, Chichester.

Green, C.P., McGregor, D.F.M. 1990. Pleistocene gravels of the north Norfolk coast. Proceedings of the Geologists' Association, 101, 197-202.

Hamblin, R.J.O, Moorlock, B.S.P., Rose, J. 2000. A New Glacial Stratigraphy for Eastern England. Quaternary Newsletter, 92, 35-43.

Hamblin, R.J.O., Moorlock, B.S.P., Rose, J., Lee, J.R., Riding, J.B., Booth, S.J., Pawley, S.M. 2005. Revised Pre-Devensian glacial stratigraphy in Norfolk, England, based on mapping and till provenance. Geologie en Mijnbouw, 84, 77-85.

Hart, J.K. 1987. The genesis of the north east Norfolk Drift. Unpublished PhD thesis, University of East Anglia.

Hart, J.K. 1992. Sedimentary environments associated with Glacial Lake Trimingham, Norfolk, UK. Boreas, 21, 119-136.

Hart, J.K., Hindmarsh, R.C.A., Boulton, G.S. 1990. Styles of subglacial glaciotectonic deformation within the context of the Anglian ice-sheet. Earth Surface Processes and Landforms, 15, 227-241.

Hart, J.K., Boulton, G.S. 1991. The interrelation of glaciotectonic and glaciodepositional processes within the glacial environment. Quaternary Science Reviews, 10, 335-350.

Hart, J.K., Roberts, D.H. 1994. Criteria to distinguish between subglacial glaciotectonic and glaciomarine deformation. I. Deformation styles and sedimentology. Sedimentary Geology, 91, 191-213. 
Hey, R.W. 1976. Provenance of far travelled pebbles in the pre-Anglian Pleistocene of East Anglia. Proceedings of the Geologists' Association, 87, 69-82.

Hey, R.W, Brenchley, P.J. 1977. Volcanic pebbles from the Pleistocene gravels in Norfolk and Essex. Geological Magazine, 114, 219-225

Hicock, S.R., Dreimanis, A. 1992. Deformation till in the Great Lakes Region: implications for rapid ice flow along the south-central margin of the Laurentide Ice Sheet. Canadian Journal of Earth Sciences, 29, 1565-1579.

Hoffmann, K. and Piotrowski, J.A. 2001. Till melange at Amsdorf, central Germany: sediment erosion, transport and deposition in a complex, soft-bedded glacial system. Sedimentary Geology, 140, 215-234.

Komatsu, T. 1999. Sedimentology and sequence stratigraphy if a tide- and wavedominated coastal succession: the Cretaceous Goshoura Group, Kyushu, southwest Japan. Cretaceous Research, 20, 327-342.

Lee, J.R. 2001. Genesis and palaeogeographic significance of the Corton Diamicton (basal member of the North Sea Drift Formation), East Anglia, UK. Proceedings of the Geologist's Association, 112, 43-67.

Lee, J.R. 2003. Early and Middle Pleistocene lithostratigraphy and palaeoenvironments in northern East Anglia, UK. Unpublished PhD Thesis, Royal Holloway University of London.

Lee, J.R., Phillips, E. 2008. Progressive soft sediment deformation within a subglacial shear zone - a hybrid mosaic-pervasive deformation model for Middle Pleistocene glaciotectonised sediments from Eastern England. Quaternary Science Reviews, 27, 13501362. 
Lee, J.R., Rose, J., Riding, J.B., Hamblin, R.J.O., Moorlock, B.S.P. 2002. Testing the case for a Middle Pleistocene Scandinavian glaciation in Eastern England: evidence for a Scottish ice source for tills within the Corton Formation of East Anglia, UK. Boreas, 31, 345-355.

Lee, J.R., Booth, S.J., Hamblin, R.J.O., Jarrow, A.M., Kessler, H., Moorlock, B.S.P., Morigi, A.N., Palmer, A., Pawley, S.J., Riding, J.B., Rose, J. 2004a. A new stratigraphy for the glacial deposits around Lowestoft, Great Yarmouth, North Walsham and Cromer, East Anglia, UK. Bulletin of the Geological Society of Norfolk, 53, 3-60.

Lee, J.R., Rose, J., Hamblin, R.J.O., Moorlock, B.S.P. 2004b. Dating the earliest lowland glaciation of eastern England: the pre-Anglian early Middle Pleistocene Happisburgh Glaciation. Quaternary Science Reviews, 23, 1551-1566.

Lee, J.R., Rose, J., Candy, I., Barendregt, R.W. 2006. Sea-level changes, river activity, soil development and glaciation around the western margins of the southern North Sea Basin during the Early and early Middle Pleistocene: evidence from Pakefield, Suffolk, UK. Journal of Quaternary Science, 21, 155-179.

Lee, J.R., Barendregt, R.W., Hamblin, R.J.O., Moorlock, B.S.P., Pawley, S.M., Phillips, E.R., Riding, J.B., Rose, J. The extent and timing of Early and Middle Pleistocene glaciations in the British Isles. In preparation.

Lewis, S.G. 1993. The status of the Wolstonian Glaciation in the English Midland and East Anglia. Unpublished PhD Thesis, University of London.

Lunkka, J.P. 1994. Sedimentation and lithostratigraphy of the North Sea Drift and Lowestoft Till Formations in the coastal cliffs of northeast Norfolk, England. Journal of Quaternary Science, 9, 209-233. 
Published in Proceedings of the Geologist's Association, 2009, Volume 120, pages 34-48.

Mazumder, R., Arima, M. 2005. Tidal rhythmites and their implications. Earth Science Reviews, 69, 79-95.

Mitchell, G.F., Penny, L.F., Shotton., F.W., West, R.G. 1973. A correlation of Quaternary deposits in the British Isles. Geological Society of London Special Report.

McKee, E.D, Goldberg, M. 1969. Experiments on formation of contorted structures in mud. Bulletin of the Geological Society of America, 80, 231-244.

Menzies, J., van der Meer, J.J.M. and Rose, J. 2006. Till - as a glacial "tectomict", its internal architecture, and the development of a "typing" method for till differentiation. Geomorphology, 75, 172-200.

Ó Cofaigh, C, Evans, D.J.A. 2001. Deforming bed conditions associated with a major ice stream of the last British Ice Sheet. Geology, 29, 795-798.

Pawley, S.M., Rose, J., Lee, J.R., Hamblin, R.J.O., Moorlock, B.S.P. 2004. Middle Pleistocene stratigraphy of Weybourne, north-east Norfolk, England. Proceedings of the Geologists' Association, 115, 22-42.

Perrin, R.M.S., Rose, J., Davies, H. 1979. The distribution, variation and origins of preDevensian tills in eastern England. Philosophical Transactions of the Royal Society of London, B287, 535-570.

Piotrowski, J.A. and Kraus, A. 1997. Response of sediment to ice sheet loading in northwestern Germany: effective stresses and glacier bed stability. Journal of Glaciology, 43, 495-502.

Piotrowski, J.A., Larsen, N.K. and Junge, F.W. 2004. Reflections on soft subglacial beds as a mosaic of deforming and stable spots. Quaternary Science Reviews, 23, 993-1000. 
Preece, R.C. 2001. Molluscan evidence for differentiation of interglacials within the 'Cromerian Complex'. Quaternary Science Reviews, 20, 1643-1656.

Preece, R.C., Parfitt, S.A. 2000. The Cromer Forest-bed Formation: new thoughts on an old problem. In: Lewis, S.G., Whiteman, C.A. \& Preece, R.C. (eds). The Quaternary of Norfolk and Suffolk, Field Guide, Quaternary Research Association, London, 1-27.

Preece RC, Parfitt SA. 2007. The Cromer Forest-bed Formation: some recent developments relating to early human occupation and lowland glaciation. In: Candy I, Lee JR, Harrison AM (eds). The Quaternary of northern East Anglia, Field Guide, Quaternary Research Association, London, 53-72.

Preece, R.C. Parfitt, S.A., Coope, G.R., Penkman, K.E.H., Parnell, P., Whittaker, J.E. 2008. Biostratigraphic and amino-acid constraints on the age of the Middle Pleistocene glacial succession of Norfolk. Journal of Quaternary Science, submitted.

Read, A., Godwin, M., Mills, C.A., Juby, C., Lee, J.R., Palmer, A.P., Candy, I., Rose, J. 2007. Evidence for Middle Pleistocene temperate-climate high sea-level and lowland-scale glaciation, Chapel Hill, Norwich, UK. Proceedings of the Geologists' Association, 118, 143-156.

Reid, C. 1882. The geology of the country around Cromer. Memoirs of the Geological Survey, England and Wales.

Reineck, H.-E., Wunderlich, F. 1968. Classification and origin of flaser and lenticular bedding. Sedimentology, 11, 99-104.

Reinson, G.E. 1992. Transgressive barrier island and estuarine systems. In: Walker, R.G., James, N.P. (eds.). Facies Models: response to sea-level change. Geological Association of Canada, Spittsville, Ontario, pp.179-194. 
Rose, J. 1987. Status of the Wolstonian Glaciation in the British Quaternary. Quaternary Newsletter, 53, 1-9.

Rose, J. 2006. A perspective on D.R. Bridgland's paper 'The Middle and Upper Pleistocene sequence in the Lower Thames: a record of Milankovitch climatic fluctuation and early human occupation of southern Britain'. Proceedings of the Geologists’'Association, 117, 227-229.

Rose, J., Gulamali, N., Moorlock, B.S.P., Hamblin, R.J.O., Jeffery, D.H., Anderson, E., Lee, J.A., Riding, J.B. 1996. Pre-glacial Quaternary sediments, How Hill near Ludham, Norfolk, England. Bulletin of the Geological Society of Norfolk, 45, 3-28.

Rose, J., Lee, J.A., Candy, I., Lewis, S.G. 1999a. Early and Middle Pleistocene river systems in eastern England: evidence from Leet Hill, southern Norfolk, England. Journal of Quaternary Science, 14, 347-360.

Rose, J., Whiteman, C.A., Allen, P., Kemp, R.A. 1999b. The Kesgrave sands and gravels: 'pre-glacial' Quaternary deposits of the River Thames in East Anglia and the Thames Valley. Proceedings of the Geologists' Association, 110, 93-116.

Rose, J., Moorlock, B.S.P., Hamblin, R.J.O. 2001. Pre-Anglian fluvial and coastal deposits in Eastern England: lithostratigraphy and palaeoenvironments. Quaternary International, 79, $5-22$.

Rose, J., Candy, I., Moorlock, B.S.P., Wilkins, H., Lee, J.A., Hamblin, R.J.O., Lee, J.R., Riding, J.B., Morigi, A.N. 2002. Early and early Middle Pleistocene river, coastal and neotectonic processes, southeast Norfolk, England. Proceedings of the Geologists' Association, 113, 47-67.

Tzedakis PC, Andrieu V, de Beaulieu J-L, Birks HJB, Crowhurst S, Follieri M, Hooghiemstra H, Magri D, Reille M, Sadori L, Shackleton NJ, Wijmstra TA. 2001. 
Published in Proceedings of the Geologist's Association, 2009, Volume 120, pages 34-48.

Establishing a terrestrial chronological framework as a basis for biostratigraphical comparisons. Quaternary Science Reviews, 20: 1583-1592.

van der Meer, J.J.M., Menzies, J. and Rose, J., 2003. Subglacial till: the deforming glacier bed. Quaternary Science Reviews, 22, 1659-1685.

West, R.G. 1980. The pre-glacial Pleistocene of the Norfolk and Suffolk coasts. Cambridge University Press, Cambridge.

Whiteman, C.A. 2002. Implications of a Middle Pleistocene ice-wedge cast at Trimingham, Norfolk, eastern England. Permafrost and Periglacial Processes, 13, 163-170.

Whiteman, C.A., Rose, J. 1992. Thames river sediments of the British Early and Middle Pleistocene. Quaternary Science Reviews, 11, 363-375.

\section{Figure Captions}

Figure 1. (a) Location maps of the Norfolk coast showing the location of Sidestrand and logged sections. (b) Diagram showing the palaeogeography of central and eastern England during the 'Cromerian Complex' (early Middle Pleistocene) showing the position of the major river catchments and coastline (modified from Rose et al., 2001, 2002; Lee et al., 2006).

Figure 2. Sedimentary logs for the eight logged sites at Sidestrand. The location of each log is shown in Figure 1a. Facing west.

Figure 3. (a) Organic clays (Unit C) containing Unio shells (US) occupying a shallow channel cut into unit B at Site T. Facing west. (b) Interlayered sands and silty-clays (Unit J) showing synsedimentary dewatering structures (DW) in the footwall block (FWB) of a major thrust at Site S. Hangingwall block (HWB). Facing west. (c) Photograph showing the internal structure of Unit K and its contact with Unit J ay Site W, note the disharmonic and 
Published in Proceedings of the Geologist's Association, 2009, Volume 120, pages 34-48. open fold structures (DF) and wispy (WB) and flame-like (FS) contacts. Fold axis (fa). Facing west. (d) Dark grey matrix-supported diamicton (Unit N) overlying highly deformed sands and silts containing Unio shells (Unit M) at Site U. The base of the Unit N is characterised by a series of sub-horizontal shears that have detached the upper limb of a fold. Fold axes (fa), Unio shells (US). Facing West.

Figure 4. Equal-area lower hemisphere stereographic projection showing the dip azimuth and dip angle of thrusts within the sections at Sidestrand. The principal eigenvectors (Pmax - V1; P-intermediate - V2; P-min - V3) are shown on the projection and demonstrate the application of stress from the north to northwest.

Figure 5. Geological map showing the provenance of clast and heavy mineral lithologies commonly found within East Anglia. Superimposed upon this is the preglacial drainage and approximate position of the coastline (modified from Rose et al., 1999a; Lee et al., 2004b, 2006).

Figure 6. Ternary diagram showing plots of heavy mineral groups from samples at Sidestrand. \% Amphibole, epidote and pyroxene is typical of a far-travelled northern source; \% Zircon, glauconite and garnet characterises residual marine ('Crag') reworking; $\%$ Collophane, tourmaline, staurolite, rutile, kyanite and others is typical of derivation from Mesozoic bedrock sources in Central England.

Figure 7. Tectono-stratigraphic model for the structural evolution of the Sidestrand succession. Four stages are defined: D1i - thrust-induced brittle deformation; D1ii ductile deformation of hanging-wall block; D2 - ductile deformation; D3 - stratigraphic inversion caused by thrusting (brittle) of older material over younger; D4i - dewatering; D4ii - ductile deformation.

\section{Table Captions}


Published in Proceedings of the Geologist's Association, 2009, Volume 120, pages 34-48.

Table 1. The stratigraphy of Early and early Middle Pleistocene marine, fluvial and glacial deposits in northern East Anglia (after Rose et al., 2001; Lee et al., 2006). Members highlighted in bold are present at the site.

Table 2. Particle size distributions of bulk samples analysed from Sidestrand.

Table 3. Clast lithological composition $(8-16 \mathrm{~mm}$ fraction) of gravel samples collected from Units A and B at Sidestrand showing bulk counts (a) and selective lithological subdivisions (b).

Table 4. Heavy mineral counts of fine sands from Units B-M at Sidestrand. Counts are expressed as total percentage opaques, and percentages of total non-opaques. Significant mineralogical groupings, based upon provenance, are also included at the base of the table.

Table 5. Summary table showing the stratigraphy of the preglacial and basal glacial deposits at Sidestrand, outlining the main lithofacies and their environmental and stratigraphic interpretations. 
SITE S

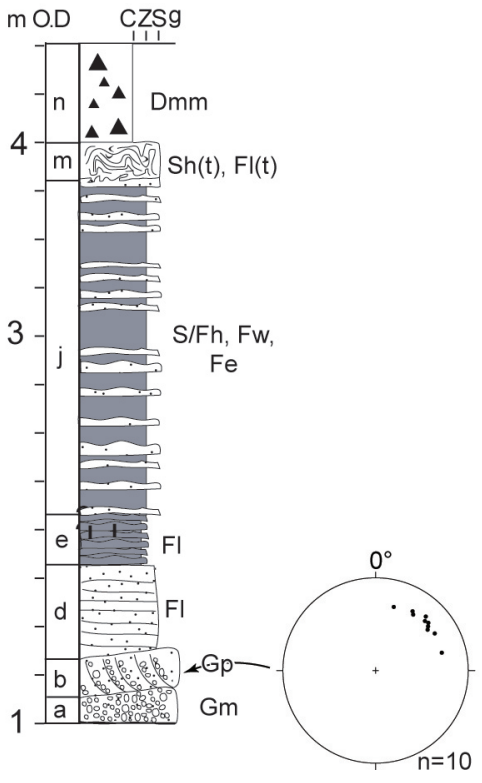

SITE U

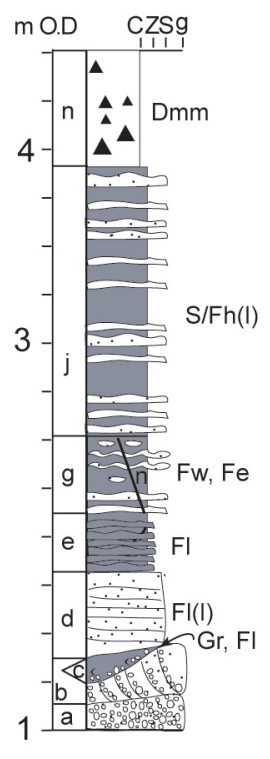

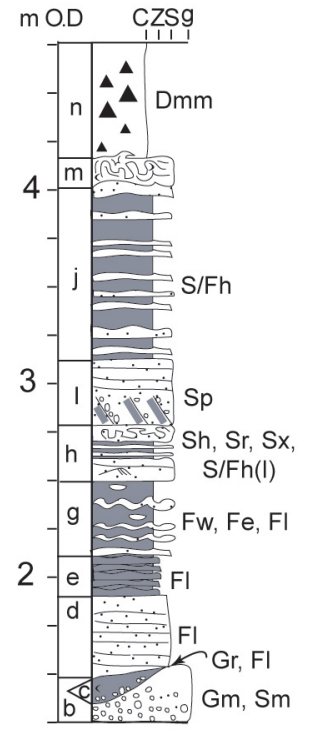

SITE $Y$

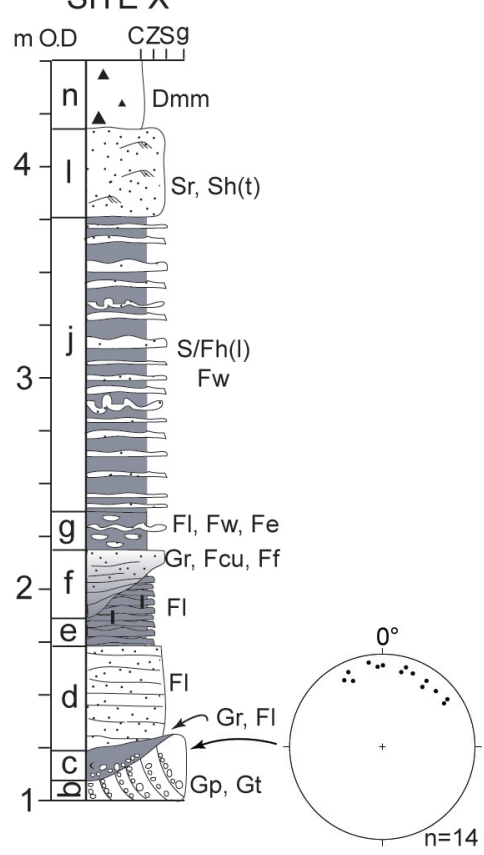

SITE V

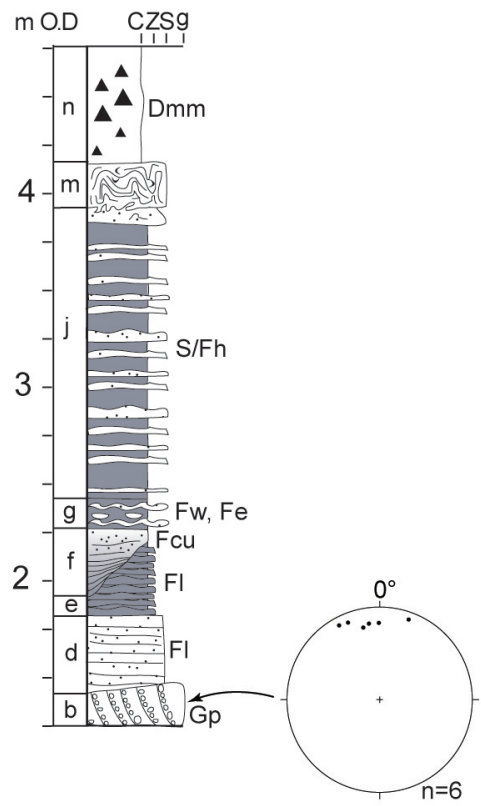

SITE Z
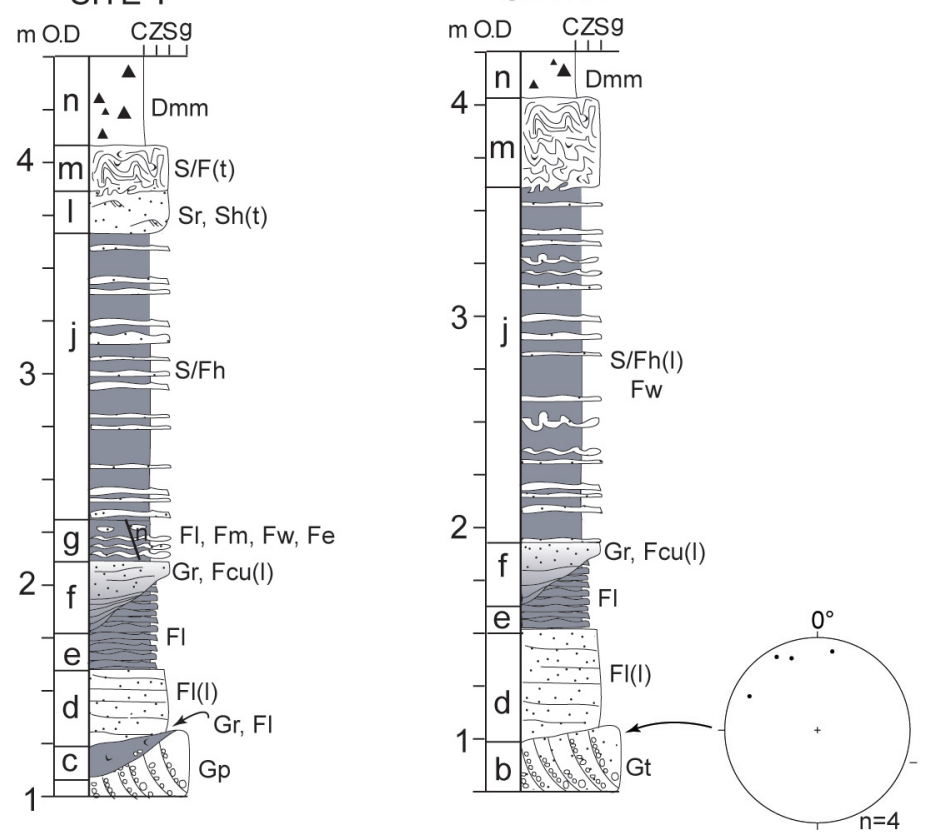

\section{KEY TO LITHOFACIES CODES}

Dmm - Diamicton, matrix-supported Gp- Gravel, planar cross-bedded Gm - Gravel, massive $\mathrm{Gr}$ - Gravel lag

Sm - Sand, massive

$\mathrm{Sp}$ - Sand, planar cross-bedded

Sx - Sand, hummocky cross-bedding

Sh - Sand, horizontal bedding

$\mathrm{Sr}$ - Sands, rippled

$\mathrm{S} / \mathrm{Fh}$ - Sands and fines, rhythmically bedded
TEXTURE

FI - Fines, rhythmically bedded / laminated C-clay;Z-silt;S-sand;g - gravel

$\mathrm{Ff}$ - Fines, flaser bedding

Fm - Fines, massive

Fw - Fines, wavy bedding

Fe - Fines, lenticular bedding

Fcu - Fines, coarsening up

---(I) - load-induced structures

---(t) - tectonic structures

\section{STRUCTURES}

$\begin{array}{ll}4 & \text { Shell } \\ \downarrow^{\mathrm{n}} & \text { Faults - normal / } \\ \text { reverse or thrust }\end{array}$

尺्a Folding 

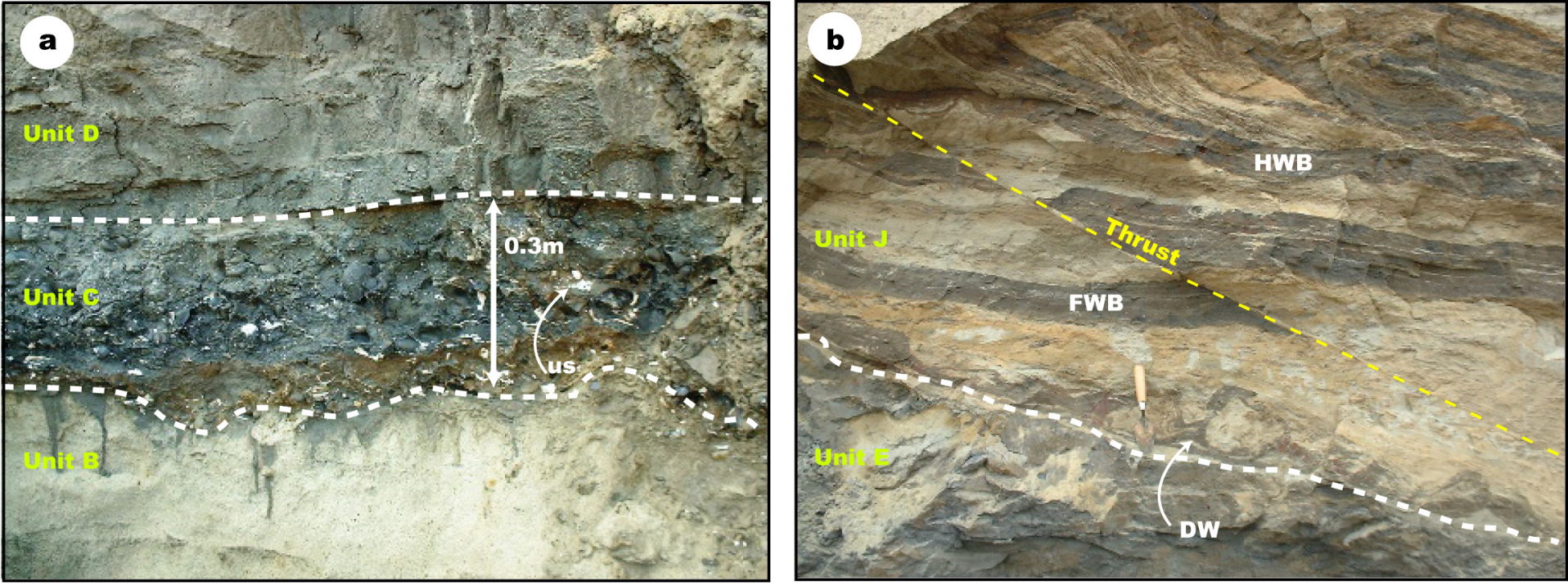

\section{c}

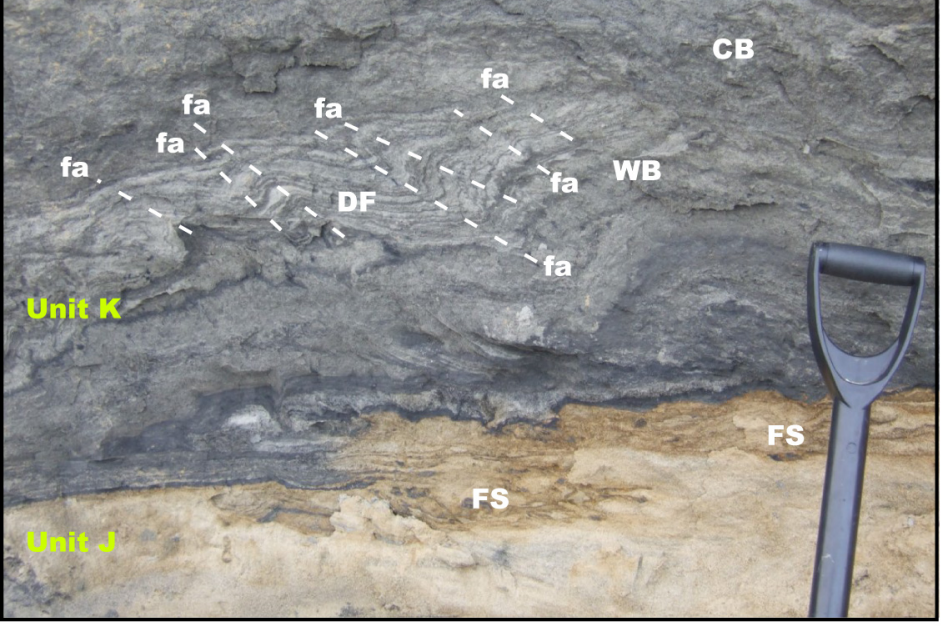

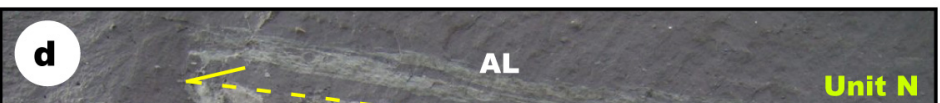

$37->-\cdots$

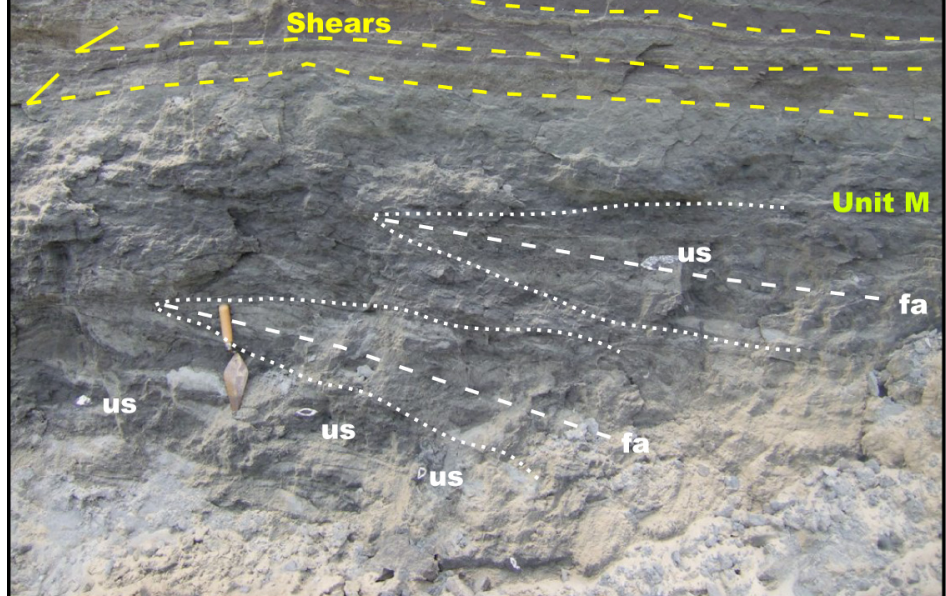

Figure 3 


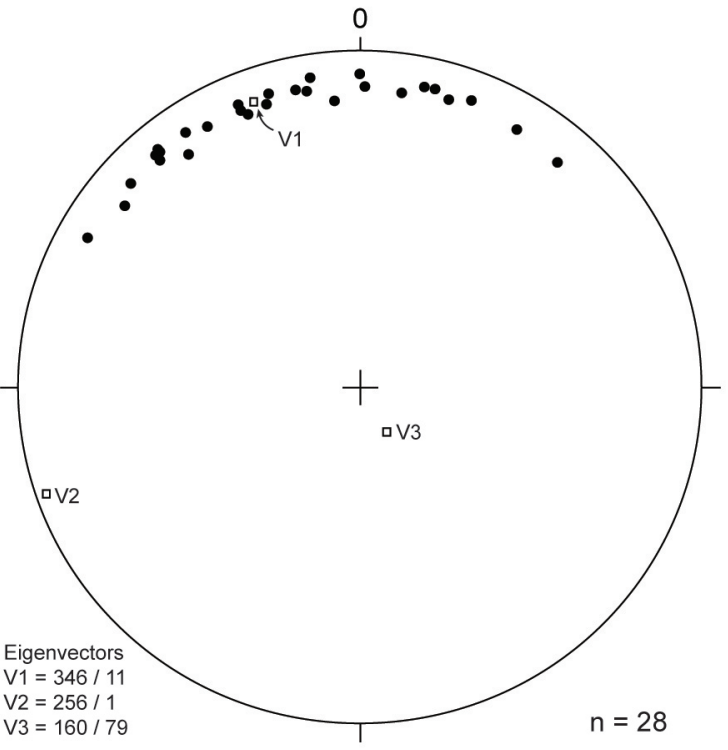

Figure 4 


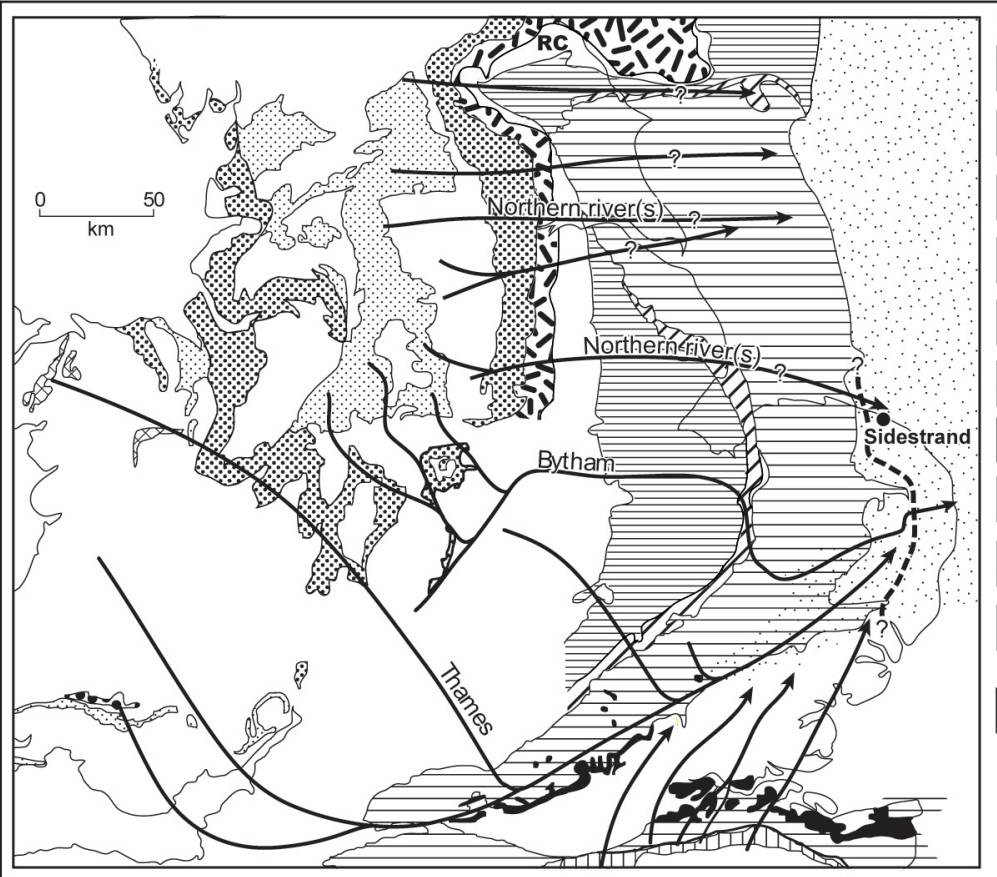

\section{Indicator lithologies}

Acid volcanic rocks of Showdonia

20 and Berwyn Mountains

Devonian sandstones, vein quartz

and quartzites

Carboniferous sandstones, vein

\% Triassic sandstones, quartzose; zircon, kyanite, staurolite, tourmaline

1. Lower Jurassic - Lias mudstone, limestone

E Upper Jurassic - collophane

॥|П Lower Greensand chert

77 Lower Cretaceous - glauconitic sandstone; collophane

ए

Cretaceous chalk and black flint

Tertiary chatter-marked flint

Pleistocene shallow marine - white and

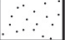

brown flint, white quartzose, garnet (fluvial input); amphibole, epidote, pyroxene, apatite (glacial input)

RC Rhaxella chert

-_u- Possible position of preglacial coastline

Alignment of preglacial rivers

\section{FIGURE 5}




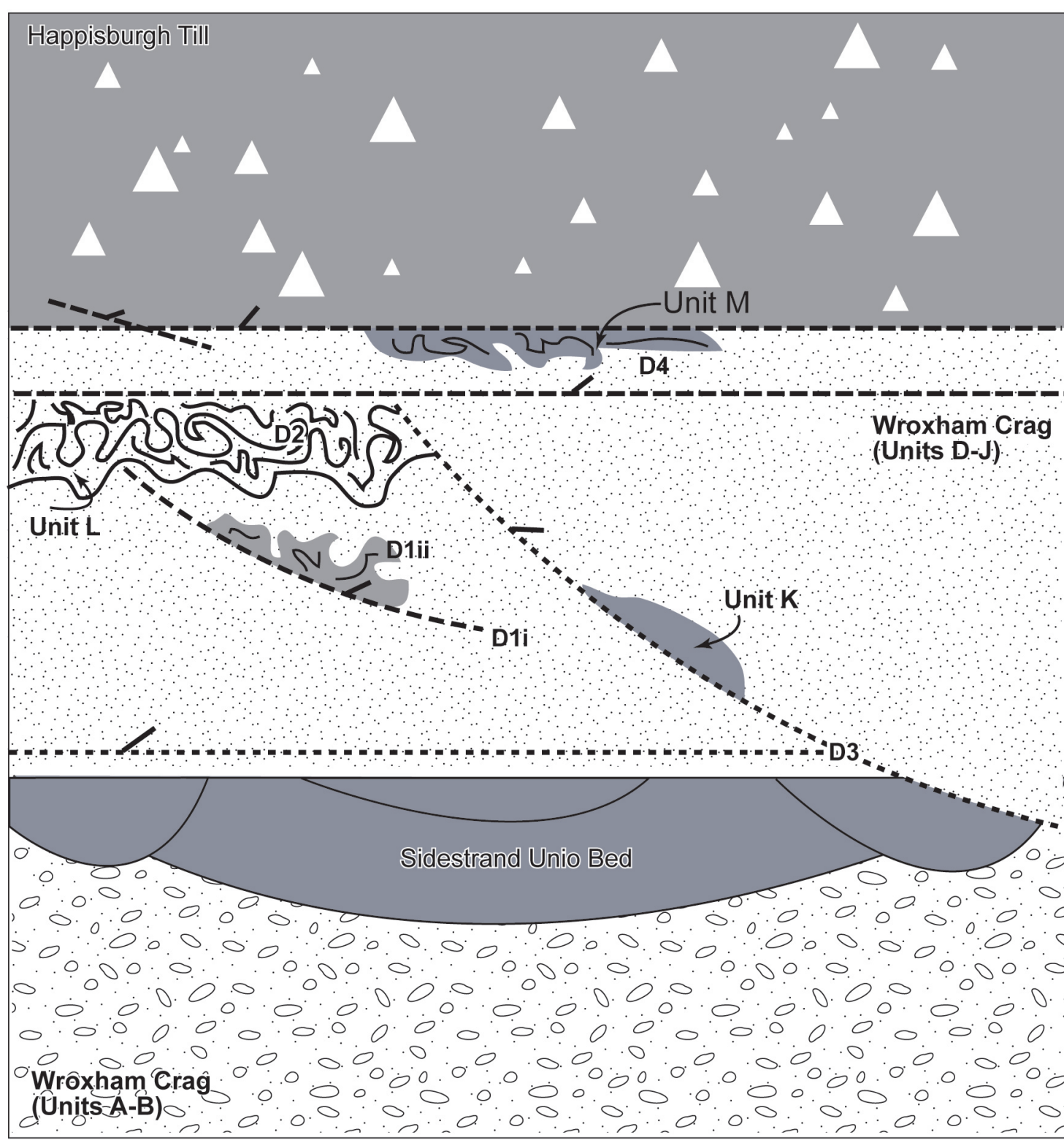

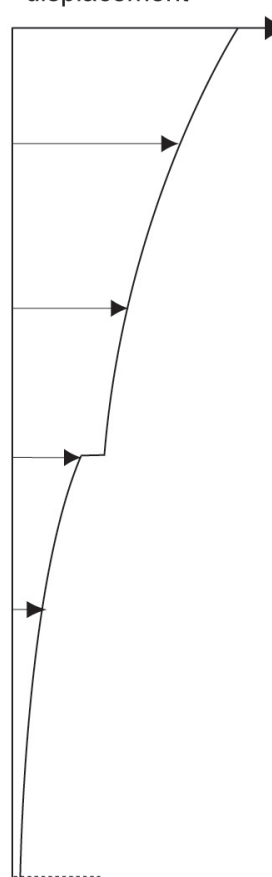

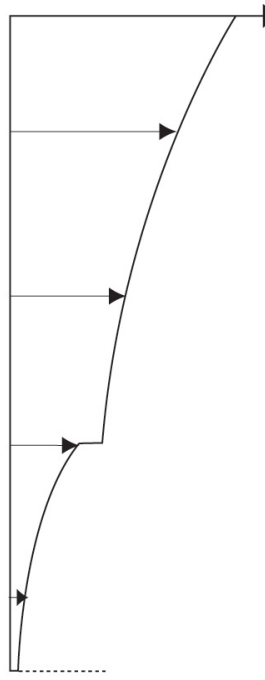

D2

D1 time

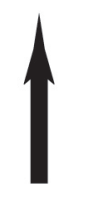

Intergranular
Porewater Content

Figure 7 


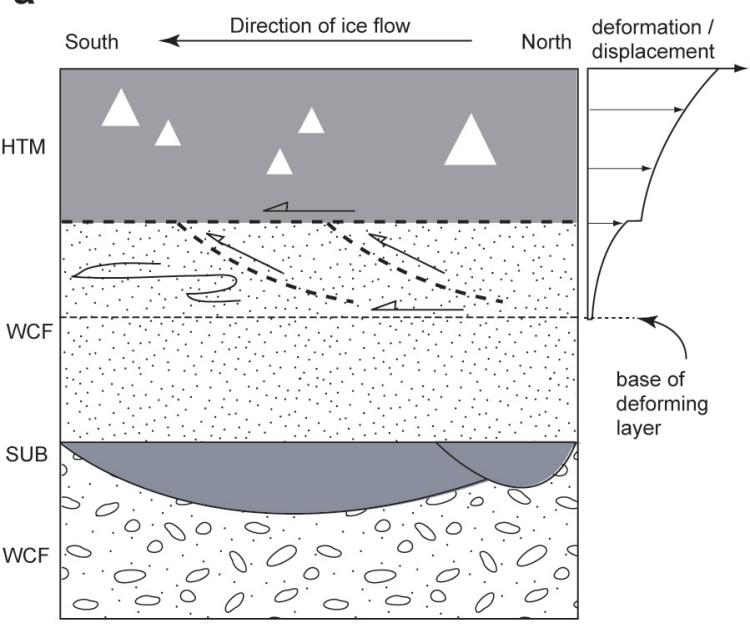

b

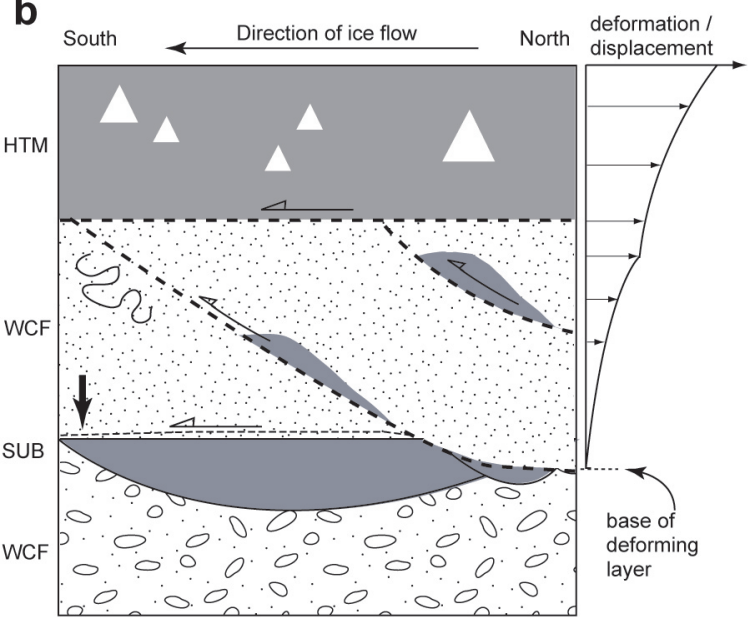

C
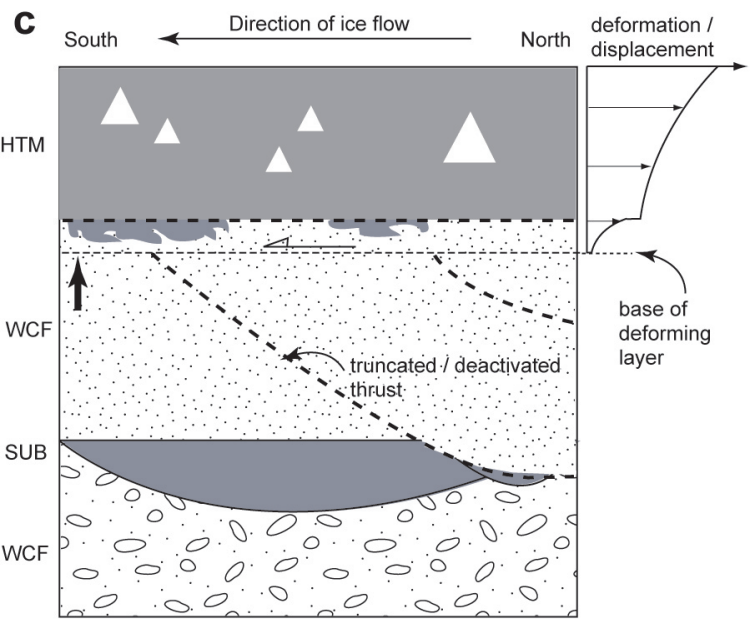

Figure 8 


\begin{tabular}{|c|c|c|c|}
\hline Lithostratigraphy & Lithology & Environment & Chronostratigraphy \\
\hline \multicolumn{4}{|l|}{ Lowestoft Formation } \\
\hline Lowestoft Till / Walcott Till Mem. & Chalky tills & Subglacial & Anglian (MIS 12) \\
\hline \multicolumn{4}{|l|}{ Wroxham Crag Formation } \\
\hline $\begin{array}{l}\text { Happisburgh Formation } \\
\text { Corton Till Member } \\
\text { Happisburgh Sand Member } \\
\text { Ostend Clay Member } \\
\text { Happisburgh Till Member }\end{array}$ & $\begin{array}{l}\text { Sandy till } \\
\text { Stratified sands } \\
\text { Laminated silts, clays } \\
\text { Sandy till }\end{array}$ & $\begin{array}{l}\text { Subaqueous till } \\
\text { Proximal glaciolacustrine } \\
\text { Distal glaciolacustine } \\
\text { Subglacial till }\end{array}$ & $\begin{array}{c}\text { Happisburgh Glaciation } \\
\text { 'Cromerian Complex' } \\
\text { MIS 16? }\end{array}$ \\
\hline Cromer Forest-bed Formation & $\begin{array}{l}\text { Organic silts, clays and } \\
\text { sands }\end{array}$ & Alluvial & 'Cromerian Complex’' \\
\hline \multicolumn{4}{|l|}{ Bytham Group } \\
\hline $\begin{array}{l}\text { Wroxham Crag Formation } \\
\text { Mundesley Member } \\
\text { How Hill Member } \\
\text { Dobbs Plantation Member }\end{array}$ & $\begin{array}{l}\text { Flint-rich sands and } \\
\text { gravels with quartzose and } \\
\text { northern lithologies }\end{array}$ & Shallow marine coastal & $\begin{array}{c}\text { Early Pleistocene } \\
\text { to } \\
\text { early Middle Pleistocene }\end{array}$ \\
\hline Norwich Crag Formation & $\begin{array}{l}\text { Flint-rich gravels, sands, } \\
\text { tidal rhythmites }\end{array}$ & Shallow marine, coastal & Early Pleistocene \\
\hline
\end{tabular}

Table 1. 


\begin{tabular}{|c|c|c|c|c|c|c|c|c|c|c|}
\hline $\begin{array}{l}\text { Sample } \\
\text { Number }\end{array}$ & $\begin{array}{l}\% \\
\text { Clay }\end{array}$ & $\begin{array}{l}\% \\
\text { Silt } \\
\end{array}$ & $\begin{array}{l}\% \\
\text { Sand }\end{array}$ & $\begin{array}{l}\% \\
\text { Gravel }\end{array}$ & $\begin{array}{l}\text { Fines } \\
\text { Mode }(\phi)\end{array}$ & $\begin{array}{l}\text { Sand } \\
\text { mode }(\phi)\end{array}$ & $\begin{array}{l}\text { Gravel } \\
\operatorname{mode}(\phi)\end{array}$ & $\begin{array}{l}\text { Total } \\
\text { sample (kg) }\end{array}$ & $\begin{array}{l}\% \\
\mathrm{CaCO} 3\end{array}$ & Lithofacies \\
\hline 60706 & 24.41 & 21.84 & 25.12 & 1.63 & +9 & +4 & -2 & 4.100000 & 11.96 & $\mathrm{~N}$ \\
\hline 60801 & 21.72 & 25.30 & 51.86 & 1.11 & +9 & +4 & -3 & 4.507000 & 12.21 & $\mathrm{~N}$ \\
\hline 60803 & 24.17 & 21.96 & 51.30 & 2.58 & +9 & +3 & -3 & 5.328000 & 13.10 & $\mathrm{~N}$ \\
\hline 60804 & 28.80 & 20.26 & 49.89 & 2.05 & +9 & +4 & -3 & 4.134000 & 11.04 & $\mathrm{~N}$ \\
\hline S30 & 37.96 & 34.09 & 26.73 & 1.22 & +6 & +3 & -4 & 5.210600 & 31.67 & $\mathrm{M}$ \\
\hline S29 & 22.81 & 23.40 & 52.18 & 1.61 & +7 & +3 & -4 & 6.502400 & 18.51 & M \\
\hline S28 & 42.61 & 36.31 & 18.24 & 2.84 & +8 & +2 & -3 & 6.247300 & 29.73 & M \\
\hline S27 & 21.41 & 44.15 & 34.13 & 0.31 & +6 & +4 & -3 & 5.824100 & 12.57 & $\mathrm{M}$ \\
\hline S26 & 56.44 & 31.66 & 11.02 & 0.88 & +7 & +4 & -3 & 6.812700 & 15.91 & M \\
\hline S13 & 1.08 & 9.01 & 89.91 & & +6 & +2 & & 0.112500 & 2.01 & $\mathrm{~J}$ \\
\hline $\mathrm{S} 12$ & 0.92 & 8.92 & 90.16 & & +5 & +2 & & 0.132400 & 0.91 & $\mathrm{~J}$ \\
\hline S11 & 3.53 & 11.13 & 85.34 & & +6 & +2 & & 0.131200 & 1.84 & $\mathrm{~J}$ \\
\hline $\mathrm{S} 10$ & 0.61 & 7.32 & 92.07 & & +6 & +2 & & 0.102400 & 0.34 & $\mathrm{~J}$ \\
\hline S19 & 8.90 & 15.77 & 75.33 & & +6 & +3 & & 0.126300 & 3.55 & $\mathrm{G}$ \\
\hline S18 & 18.26 & 10.44 & 71.30 & & +7 & +3 & & 0.147700 & 8.09 & $\mathrm{G}$ \\
\hline S17 & 1.21 & 20.58 & 78.21 & & +5 & +2 & & 0.118000 & 4.73 & G \\
\hline S16 & 5.57 & 23.34 & 71.09 & & +5 & +3 & & 0.121300 & 3.36 & $\mathrm{G}$ \\
\hline S15 & 5.81 & 25.95 & 68.24 & & +5 & +2 & & 0.100300 & 5.82 & G \\
\hline S14 & 6.16 & 16.32 & 77.52 & & +5 & +3 & & 0.094500 & 6.47 & G \\
\hline S23 & 28.54 & 62.27 & 9.19 & & +6 & +3 & & 0.162400 & 11.43 & $\mathrm{~F}$ \\
\hline S22 & 25.57 & 31.51 & 43.22 & & +5 & +3 & & 0.112400 & 6.07 & $\mathrm{~F}$ \\
\hline S21 & 10.22 & 65.61 & 24.17 & & +5 & +3 & & 0.092700 & 9.14 & $\mathrm{D}$ \\
\hline S20 & 9.21 & 59.22 & 31.57 & & +6 & +3 & & 0.121100 & 6.25 & $\mathrm{D}$ \\
\hline S09 & 72.95 & 24.91 & 0.29 & 1.85 & +9 & +4 & & 6.091000 & 18.64 & $\mathrm{C}$ \\
\hline S08 & 67.83 & 27.55 & 0.54 & 4.08 & +9 & +4 & & 5.104000 & 38.22 & $\mathrm{C}$ \\
\hline S07 & 73.69 & 23.13 & 0.34 & 2.84 & +9 & +4 & & 7.142000 & 21.29 & C \\
\hline S06 & 80.60 & 14.73 & 1.05 & 3.62 & +9 & +4 & & 8.127000 & 34.93 & $\mathrm{C}$ \\
\hline S05 & 2.01 & 0.68 & 90.09 & 7.22 & +9 & +1 & -3 & 11.78400 & 1.38 & B \\
\hline S03 & 1.87 & 1.09 & 88.30 & 8.74 & +9 & +2 & -3 & 10.04100 & 0.41 & B \\
\hline PG3B & 2.66 & 0.94 & 80.01 & 16.39 & +9 & +2 & -3 & 10.62400 & 0.70 & B \\
\hline PG3D & 2.78 & 1.11 & 85.85 & 10.26 & +9 & +1 & -2 & 9.261000 & 0.92 & B \\
\hline SD04 & 2.84 & 0.77 & 61.78 & 34.61 & +9 & +2 & -3 & 8.852000 & 0.22 & $\mathrm{~A}$ \\
\hline
\end{tabular}

TABLE 2 


\begin{tabular}{|c|c|c|c|c|c|c|c|c|c|c|c|c|c|c|c|c|c|c|c|c|c|c|}
\hline & \multirow[b]{2}{*}{$\mathrm{n}$} & \multicolumn{3}{|c|}{ Carboniferous } & \multicolumn{2}{|c|}{ Triassic } & \multirow[b]{2}{*}{ schorl } & \multirow[b]{2}{*}{ Total } & \multicolumn{2}{|c|}{ Jurassic } & \multirow[b]{2}{*}{ Total } & \multicolumn{2}{|c|}{ Cretaceous } & \multirow[b]{2}{*}{$\begin{array}{c}\text { Green' } \\
\text { cht }\end{array}$} & \multirow[b]{2}{*}{ Chalk } & \multirow[b]{2}{*}{ Flint } & \multirow[b]{2}{*}{ Total } & \multirow{2}{*}{$\begin{array}{c}\text { Cenozoic } \\
\text { c-m } \\
\text { flint }\end{array}$} & \multirow[b]{2}{*}{$\begin{array}{l}\text { Total } \\
\text { Flint }\end{array}$} & \multirow{2}{*}{$\begin{array}{c}\text { Exotics } \\
\text { North } \\
\text { UK }\end{array}$} & \multirow[b]{2}{*}{ Wales } & \multirow[b]{2}{*}{$\begin{array}{l}\text { Unk- } \\
\text { nowr }\end{array}$} \\
\hline & & sst & cht & Total & qtzite & v.qtz & & & $\begin{array}{l}R h x \\
\text { cht }\end{array}$ & $\begin{array}{l}\text { sst, lst, } \\
\text { irst, sh }\end{array}$ & & $\begin{array}{l}\text { sst, lst, } \\
\text { irst, sh }\end{array}$ & $\begin{array}{c}\text { glauc } \\
\text { sst }\end{array}$ & & & & & & & & & \\
\hline \multicolumn{23}{|l|}{ Bed B } \\
\hline PG3D & 515 & 0.0 & 0.6 & 0.6 & 7.2 & 21.4 & 0.8 & 29.4 & 0.4 & 1.6 & 2.0 & 0.0 & 0.0 & 1.4 & 0.2 & 59.9 & 61.5 & 8.3 & 68.1 & 0.6 & 0.0 & 0.2 \\
\hline PG3B & 506 & 0.0 & 0.2 & 0.2 & 3.8 & 33.2 & 1.8 & 38.8 & 0.2 & 1.0 & 1.2 & 0.0 & 0.0 & 1.4 & 0.0 & 49.8 & 51.2 & 7.5 & 57.3 & 1.0 & 0.0 & 0.0 \\
\hline $\mathrm{S} 03$ & 407 & 0.7 & 0.3 & 1.0 & 4.9 & 22.6 & 0.2 & 27.8 & 0.2 & 1.2 & 1.4 & 0.0 & 0.0 & 1.2 & 0.0 & 60.2 & 61.4 & 7.6 & 67.8 & 0.7 & 0.0 & 0.0 \\
\hline S05 & 466 & 0.4 & 1.3 & 1.7 & 5.8 & 25.3 & 0.2 & 31.3 & 0.4 & 0.6 & 1.0 & 0.4 & 0.0 & 0.4 & 0.0 & 56.7 & 57.5 & 7.3 & 63.9 & 0.9 & 0.0 & 0.2 \\
\hline \multicolumn{23}{|l|}{ Bed A } \\
\hline SD04 & 311 & 1.0 & 0.6 & 2.6 & 7.4 & 20.9 & 0.0 & 28.3 & 0.6 & 0.0 & 0.6 & 0.0 & 0.0 & 0.6 & 0.0 & 51.4 & 52.1 & 13.5 & 65.0 & 2.3 & 0.0 & 0.6 \\
\hline
\end{tabular}

Table 3(a). Lithological composition of the $8-16 \mathrm{~mm}$ gravel fraction from Beds A and B.

\begin{tabular}{|c|c|c|c|c|c|c|c|c|c|c|}
\hline & $\begin{array}{c}\text { White / } \\
\text { colourless } \\
\text { quartzose }\end{array}$ & $\begin{array}{l}\text { Coloured } \\
\text { quartzose }\end{array}$ & Total quartzose & $\begin{array}{c}\text { Quartzite : vein } \\
\text { quartz ratio }\end{array}$ & $\begin{array}{c}\text { Coloured: } \\
\text { colourless ratio }\end{array}$ & White Flint & Brown Flint & Black Flint & Total Flint & $\begin{array}{c}\text { Flint: } \\
\text { Quartzose ratio }\end{array}$ \\
\hline \multicolumn{11}{|l|}{ Bed B } \\
\hline PG3D & 23.9 & 4.7 & 29.4 & 0.3 & 0.2 & 35.9 & 12.6 & 11.4 & 68.1 & 2.3 \\
\hline PG3B & 35.2 & 1.8 & 38.8 & 0.1 & 0.1 & 23.9 & 19.4 & 6.5 & 57.3 & 1.5 \\
\hline S03 & 24.6 & 3.2 & 27.8 & 0.2 & 0.1 & 32.4 & 17.7 & 12.8 & 67.8 & 2.4 \\
\hline S05 & 27.0 & 4.3 & 31.3 & 0.2 & 0.2 & 31.8 & 18.0 & 14.2 & 63.9 & 2.0 \\
\hline \multicolumn{11}{|l|}{ Bed A } \\
\hline SD04 & 23.8 & 4.5 & 28.3 & 0.4 & 0.2 & 33.8 & 19.0 & 12.2 & 65.0 & 2.3 \\
\hline
\end{tabular}

Table 3(b). Distinctive sub-fractions of the $8-16 \mathrm{~mm}$ gravel lithologies. 


\begin{tabular}{|c|c|c|c|c|c|c|c|c|c|c|c|c|c|c|c|c|c|c|c|c|c|c|c|c|c|c|c|}
\hline Sample No. > & PG3D & PG3B & S03 & S05 & S06 & S07 & S08 & S09 & S20 & S21 & S22 & S23 & S14 & S15 & S16 & S17 & S18 & S19 & S10 & S11 & S12 & S13 & S26 & S27 & S28 & S29 & S30 \\
\hline \% Opaque & 44.3 & 44.8 & 47.2 & 45.0 & 62.7 & 63.0 & 58.7 & 63.2 & 38.0 & 49.4 & 60.3 & 50.6 & 53.7 & 44.0 & 40.6 & 41.8 & 18.6 & 15.9 & 57.7 & 57.5 & 57.7 & 59.1 & 48.2 & 49.7 & 46.2 & 48.0 & 43.7 \\
\hline \multicolumn{28}{|c|}{ Non-Opaques (\% of total non opaques) } \\
\hline $\begin{array}{l}\text { \% Amphibole } \\
\text { Grp }\end{array}$ & 19.5 & 17.5 & 16.1 & 17.6 & 7.5 & 10.8 & 11.0 & 8.0 & 38.3 & 29.5 & 22.6 & 21.2 & 33.3 & 34.1 & 36.5 & 36.6 & 43.3 & 35.8 & 18.3 & 24.4 & 25.6 & 23.5 & 33.0 & 36.2 & 10.2 & 36.4 & 22.0 \\
\hline \% Apatite Grp & 1.8 & 2.0 & 1.8 & 2.6 & 16.4 & 13.4 & 12.6 & 14.2 & 3.1 & 2.4 & 0.0 & 0.0 & 2.0 & 1.3 & 2.3 & 2.2 & 0.8 & 0.7 & 0.0 & 0.0 & 0.0 & 0.0 & 1.1 & 0.6 & 3.0 & 1.5 & 0.8 \\
\hline \% Epidote Grp & 15.5 & 19.5 & 18.3 & 15.4 & 4.1 & 5.1 & 3.8 & 5.6 & 12.9 & 7.8 & 11.3 & 7.8 & 10.1 & 13.1 & 10.0 & 11.5 & 9.8 & 8.1 & 8.3 & 10.8 & 11.1 & 13.1 & 11.4 & 9.0 & 12.7 & 9.2 & 15.6 \\
\hline \% Garnet & 18.1 & 19.0 & 21.4 & 19.4 & 6.8 & 7.6 & 7.7 & 8.8 & 22.3 & 34.9 & 36.3 & 43.5 & 25.3 & 30.6 & 29.2 & 25.6 & 26.1 & 24.0 & 40.0 & 36.4 & 36.7 & 35.5 & 29.0 & 22.6 & 31.0 & 24.6 & 32.4 \\
\hline \% Kyanite & 2.7 & 2.0 & 1.8 & 2.2 & 8.9 & 5.1 & 4.4 & 8.6 & 0.8 & 1.2 & 1.8 & 1.0 & 2.0 & 0.9 & 0.8 & 1.1 & 0.4 & 0.7 & 2.8 & 0.6 & 2.5 & 2.2 & 2.3 & 4.5 & 1.5 & 2.6 & 1.6 \\
\hline \% Glauconite & 1.8 & 2.5 & 2.7 & 2.2 & 0.7 & 1.3 & 0.5 & 1.9 & 1.2 & 0.0 & 0.0 & 0.0 & 1.0 & 0.0 & 0.8 & 1.9 & 0.4 & 15.5 & 0.0 & 0.0 & 0.0 & 0.0 & 1.1 & 1.1 & 0.0 & 1.5 & 2.4 \\
\hline \% Pyroxene & 1.8 & 1.5 & 2.2 & 1.3 & 1.4 & 0.6 & 1.1 & 0.6 & 2.3 & 2.4 & 3.0 & 3.1 & 2.0 & 3.5 & 4.6 & 4.6 & 1.2 & 1.0 & 5.0 & 1.7 & 4.0 & 2.2 & 1.1 & 0.6 & 2.0 & 0.5 & 0.8 \\
\hline \% Rutile & 5.8 & 4.0 & 4.5 & 5.3 & 11.0 & 10.8 & 9.9 & 9.9 & 3.9 & 2.4 & 4.8 & 2.6 & 5.1 & 0.9 & 0.8 & 0.8 & 0.0 & 0.0 & 1.1 & 2.3 & 3.0 & 1.1 & 2.3 & 2.8 & 8.1 & 2.6 & 2.0 \\
\hline \% Staurolite & 3.1 & 2.5 & 2.7 & 2.2 & 5.5 & 5.7 & 6.6 & 4.3 & 0.8 & 0.6 & 1.8 & 1.0 & 3.0 & 0.9 & 0.4 & 0.4 & 1.2 & 1.0 & 1.7 & 2.3 & 0.5 & 2.7 & 2.3 & 1.7 & 8.1 & 2.1 & 2.4 \\
\hline$\%$ Tourmaline & 8.8 & 7.0 & 5.4 & 7.9 & 11.0 & 12.1 & 13.7 & 17.3 & 2.7 & 4.8 & 3.6 & 3.6 & 3.0 & 1.7 & 1.5 & 1.9 & 0.8 & 0.7 & 2.8 & 3.4 & 2.0 & 2.7 & 6.8 & 9.0 & 10.2 & 7.2 & 7.6 \\
\hline \% Zircon & 20.4 & 20.5 & 23.2 & 22.5 & 24.7 & 26.8 & 27.5 & 21.0 & 10.9 & 11.4 & 14.9 & 16.1 & 1.1 & 10.0 & 10.8 & 11.5 & 14.7 & 11.8 & 20.0 & 18.2 & 14.1 & 16.9 & 9.1 & 10.7 & 122 & 10.3 & 11.2 \\
\hline$\%$ Other & 0.9 & 2.0 & 0.0 & 1.3 & 2.1 & 0.6 & 1.1 & 0.6 & 0.8 & 2.4 & 0.0 & 0.0 & 2.0 & 3.1 & 2.3 & 1.9 & 1.2 & 0.7 & 0.0 & 0.0 & 0.5 & 0.0 & 0.6 & 1.1 & 1.0 & 1.5 & 1.2 \\
\hline Sample count & 812 & 724 & 848 & 826 & 782 & 848 & 882 & 880 & 826 & 652 & 846 & 781 & 428 & 818 & 876 & 901 & 602 & 704 & 852 & 828 & 942 & 894 & 680 & 705 & 624 & 750 & 888 \\
\hline \multicolumn{28}{|l|}{ Intercomponent } \\
\hline \% Am, Ep, Px & 36.7 & 38.5 & 36.6 & 34.4 & 13.0 & 16.6 & 15.9 & 14.2 & 53.5 & 39.8 & 36.9 & 32.1 & 45.5 & 50.7 & 51.2 & 52.7 & 54.3 & 44.9 & 31.7 & 36.9 & 40.7 & 38.8 & 45.5 & 45.8 & 24.9 & 46.2 & 38.4 \\
\hline$\% \mathrm{Gt}, \mathrm{Gl}, \mathrm{Zi}$ & 40.3 & 42.0 & 47.3 & 44.1 & 32.2 & 35.7 & 35.7 & 30.9 & 34.4 & 46.4 & 51.2 & 59.6 & 37.4 & 40.6 & 40.8 & 38.9 & 41.2 & 51.4 & 60.0 & 54.5 & 50.8 & 52.5 & 39.2 & 34.5 & 43.0 & 36.4 & 46.0 \\
\hline $\begin{array}{l}\% \text { Col, Ky, R, T, } \\
\text { St, Ot }\end{array}$ & 23.0 & 19.5 & 16.1 & 21.6 & 54.8 & 47.8 & 48.4 & 54.9 & 12.1 & 13.9 & 11.9 & 8.3 & 17.2 & 8.7 & 8.1 & 8.4 & 4.5 & 3.7 & 8.3 & 8.5 & 8.5 & 8.7 & 15.3 & 19.8 & 32.0 & 17.4 & 15.6 \\
\hline Unit & B & B & B & B & C & $\mathrm{C}$ & C & $\mathrm{C}$ & $\mathrm{D}$ & $\mathrm{D}$ & $\mathrm{F}$ & $\mathrm{F}$ & G & G & G & G & G & G & $\mathrm{J}$ & $\mathrm{J}$ & $\mathrm{J}$ & $\mathrm{J}$ & $\mathrm{M}$ & $\mathrm{M}$ & $\mathrm{M}$ & M & M \\
\hline
\end{tabular}

Table 4 


\begin{tabular}{|c|c|c|c|c|}
\hline Unit & Lithofacies & Environment & Sea-level & Lithostratigraphy \\
\hline Unit N & Matrix-supported, highly consolidated diamicton. & Subglacial & & $\begin{array}{l}\text { Happisburgh Till Member } \\
\text { Happsiburgh Formation }\end{array}$ \\
\hline Unit $\mathrm{K} / \mathrm{M}$ & & Subglacial glaciotectonite & & \\
\hline Unit L & Cross-laminated, horizontall-bedded sand & Inner Estuary & T & \\
\hline Unit $J$ & Interlayered sand and silt & Tidal flats & & \\
\hline Unit I & $\begin{array}{l}\text { Planar cross-bedded sand with clay drapes } \\
\text { passing into horizontally-bedded sand; numer- } \\
\text { ous reactivation surfaces. }\end{array}$ & Estuary mouth sand bars & & \\
\hline Unit $\mathrm{H}$ & $\begin{array}{l}\text { Horizontal / rippled sand, passing upwards into } \\
\text { HCS and interlayered sand / silt; convolute } \\
\text { bedding common. }\end{array}$ & $\begin{array}{l}\text { Tidal flat beneath storm } \\
\text { wave base }\end{array}$ & 든 & \\
\hline Unit G & $\begin{array}{l}\text { Longitudinal cross-bedding, sets of lenticular } \\
\text { bedding and laminated sand / fines; intraforma- } \\
\text { tional faulting. }\end{array}$ & Tidal flat channel & 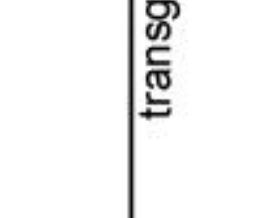 & $\begin{array}{l}\text { Mundesley Member } \\
\text { Wroxham Crag Formation }\end{array}$ \\
\hline Unit F & Channels and associated fills. & Tidal channel & & \\
\hline Unit E & Horizontal beded clayey silt. & Lagoonal & & \\
\hline Unit D & Laminated sandy silt with load structures. & Lagoonal & & \\
\hline Unit C & Channels and associated fills; Unio shells. & Freshwater fluvial & & $\begin{array}{l}\text { Sidestrand Unio Bed } \\
\text { Cromer Forest-bed Fm }\end{array}$ \\
\hline Unit B & $\begin{array}{l}\text { Cross-bedded sand and gravel; erosional lower } \\
\text { surface with rip-up clast / gravel lag; shell } \\
\text { debris. }\end{array}$ & Outer estuary gravel bar & 든 & $\begin{array}{l}\text { Mundesley Member } \\
\text { Wroxham Crag Formation }\end{array}$ \\
\hline Unit A & Crudely-stratified gravel. & Outer estuary gravel bar & & \\
\hline
\end{tabular}

\section{Table 5}

